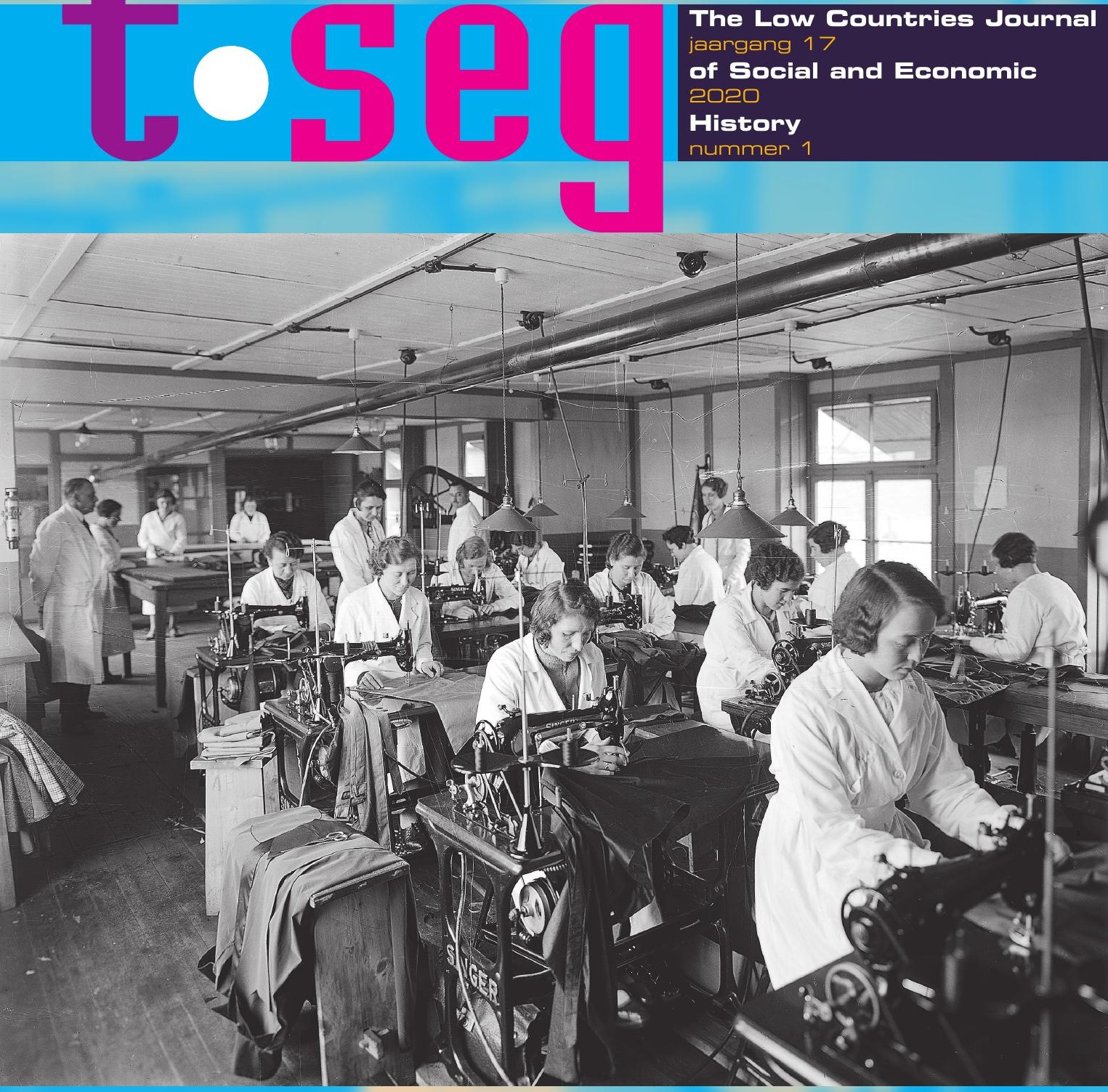

Special Issue: 'Het androcentrisme voorbij?' 25 jaar gender en sociale geschiedenis

- Arbeid van vrouwen in Limburg [Knotter]

- Androcentrisme in de historische demografie [Janssens]

- Van regionaal naar globaal [Van Nederveen Meerkerk]

- Feminationalisme [Schrover] 


\title{
Arbeid van vrouwen in Limburg in de twintigste eeuw Een stille revolutie ${ }^{1}$
}

\author{
Ad Knotter
}

TSEG $17(1): 15^{-52}$

DOI: $10.1835^{2} /$ tseg.1127

\begin{abstract}
Female labour force participation declined in Limburg from a relatively high level at the start of the twentieth century to a relatively low level at the end of that century. In this article this 'silent revolution' is analysed by focussing on the development of women's labour in agriculture, in the South Limburg mining district, and in the Maastricht glass and pottery industries. The high level of female labour force participation was, firstly, caused by a high labour input of women in small farming predominating in Limburg agriculture well into the 1950s, secondly, by the many women, both married and unmarried, employed in the Maastricht glass and pottery works. In the mining districts, by contrast, women's paid labour was almost absent (apart from employment of young, unmarried women in the clothing industry). The relative decline of female labour in the Province of Limburg is foremost a consequence of the growth of mining relative to agriculture. But in agriculture and the Maastricht industries female labour declined as well, due to the exodus of young women out of agriculture in the first, and of changes in production and employers' policies in the second case.
\end{abstract}

1 Bewerking van de rede uitgesproken op vrijdag 30 november 2018 bij mijn afscheid als hoogleraar op de door het Sociaal Historisch Centrum voor Limburg ingestelde leerstoel 'Vergelijkende regionale geschiedenis, in het bijzonder die van Limburg en aangrenzende regio's' aan de Faculteit der Cultuur- en Maatschappijwetenschappen van de Universiteit Maastricht. Een uitgebreidere tekst is als boekje uitgegeven door uitgeverij WBooks in Zwolle onder dezelfde titel. 


\section{Het debat over het mannelijke kostwinnersmodel}

In de sociaaleconomische geschiedenis van de vrouwenarbeid is het sinds het baanbrekende werk van Louise Tilly en Joan Scott, Women, Work, and Family uit 1978 gebruikelijk de arbeid van vrouwen in verband te brengen met de economische structuur van het gezin. ${ }^{2} \mathrm{Zij}$ maakten een onderscheid tussen de family economy, waarin echtparen en kinderen samenwerken, zoals in het boerengezinsbedrijf, de family wage economy, waarin gezinsleden ieder naar vermogen looninkomen inbrengen, en de family consumer economy, waarin het gezin alleen als consumptie-eenheid verschijnt op basis van het inkomen van één kostwinner, in het algemeen de man. Dit laatste model staat ook bekend als de male breadwinner family, in het Nederlands het mannelijke kostwinnersgezin. Op deze indeling is veel kritiek gekomen, ${ }^{3}$ met name op de evolutionaire implicaties ervan, maar deze modellen geven als ideaaltypen wel inzicht in de relatie tussen de gezinssituatie en de vrouwenarbeid.

Uitgangspunt van deze indeling, en sindsdien standaard in elk debat over dit onderwerp, is dat het huishouden met één mannelijke kostwinner, dat tot niet zo lang geleden dominant was in de Westerse samenleving, een historisch verschijnsel is dat in de negentiende en twintigste eeuw is opgekomen, maar niet altijd heeft bestaan. In de jaren 1950 en 196o kende het mannelijke kostwinnersgezin zijn grootste verbreiding, maar het lijkt nu weer te verdwijnen. Over het tempo en de oorzaken van de opkomst van het kostwinnersmodel wordt sinds de jaren 1990 een debat gevoerd dat tot veel onderzoek aanleiding heeft gegeven, ook in Nederland. ${ }^{4}$ Nederland is als casus interessant, omdat dit verschijnsel zich al vroeg voordeed en in de twintigste eeuw leidde tot een naar verhouding met andere landen erg lage vrouwelijke arbeidsparticipatie. ${ }^{5}$

Voor de opkomst van het mannelijke kostwinnersgezin, en de afnemende participatie van vrouwen op de arbeidsmarkt als keerzijde daar-

2 L.A. Tilly en J.W. Scott, Women, work, and family (New York 1978).

3 Zie onder meer A. Knotter, 'Problems of the family economy. Peasant economy, domestic production and labour markets in pre-industrial Europe', in: M. Prak (red.), Early modern capitalism. Economic and social change in Europe, 1400-1800 (Londen 2001) 135-160.

4 Een vroege samenvatting van dit debat geeft Angélique Janssens, 'The rise and decline of the male breadwinner family? An overview of the debate', International Review of Social History 42 (1997) Supplement, 1-23.

5 Voor een kritisch overzicht: A. Schmidt en E. van Nederveen Meerkerk, 'Reconsidering the "first malebreadwinner economy". Women's labor force participation in the Netherlands, 1600-190o', Feminist Economics 18:4 (2012) 9-96. 
van, zijn algemene verklaringen gezocht in de stijging van de lonen van mannelijke arbeiders, die een bijdrage aan het gezinsinkomen van andere gezinsleden steeds minder nodig maakte, en in het doordringen van burgerlijke opvattingen over de plaats van de vrouw in het gezin in steeds meer lagen van de bevolking. De strikte arbeidsverdeling in de mannelijke kostwinnersgezinnen en de concentratie van reproductieve en huishoudelijke taken bij vrouwen maakte een continue intensieve en productieve inzet van mannelijke werknemers in de bedrijven mogelijk. Daardoor konden weer hogere lonen worden uitbetaald, waarmee het mogelijk was te voorzien in het levensonderhoud van het hele arbeidersgezin en een bijdrage van vrouwen aan het gezinsinkomen, zoals in de family wage economy, overbodig werd. Dit verschijnsel past in het zogenoemde Fordistische bedrijfsmodel, dat volgens economisch-sociologen in de lange periode van hoogconjunctuur na de Tweede Wereldoorlog dominant werd in het Westerse kapitalisme: in navolging van autofabrikant Ford werd industriële massaproductie met een hoge arbeidsproductiviteit gecombineerd met relatief hoge lonen. ${ }^{6}$ De reproductie van de hoogproductieve mannelijke kostwinner vond plaats in het gezin door huishoudelijke arbeid van de vrouw. Het is daarom niet toevallig dat de grootste uitbreiding van het mannelijke kostwinnersgezin in de jaren 1950 en 1960 samenviel met het hoogtepunt van het Fordisme. Tegelijk werden aan huishoudelijke taken op het gebied van voeding, verzorging en opvoeding steeds meer eisen gesteld, waaraan de huisvrouw alleen door een volledige inzet kon voldoen.

\section{Lokale en regionale verschillen}

Het is echter de vraag of deze generieke verklaring voor de dalende vrouwelijke arbeidsparticipatie door de stijgende looninkomsten van de mannelijke kostwinners wel recht doet aan de grote verscheidenheid tussen bedrijfstakken en regio's. In haar recente Wageningse dissertatie uit 2017 stelt Corinne Boter dat deze verklaring aan de aanbodzijde moet worden aangevuld met verklaringen aan de vraagzijde, in het bijzonder de vraag naar arbeid van vrouwen op de lokale arbeidsmarkt. ${ }^{7}$ In de Limburgse mijnstreek bestond bijvoorbeeld nauwelijks

6 Vgl. over het 'Fordisme' in relatie met het mannelijke kostwinnersmodel ook Colin Crouch, Social change in Western Europe (Oxford 1999) 38, 201.

7 C. Boter, Dutch divergence? Women's work, structural change, and household living standards in the Netherlands, $1830-1914$ (Wageningen 2017). 


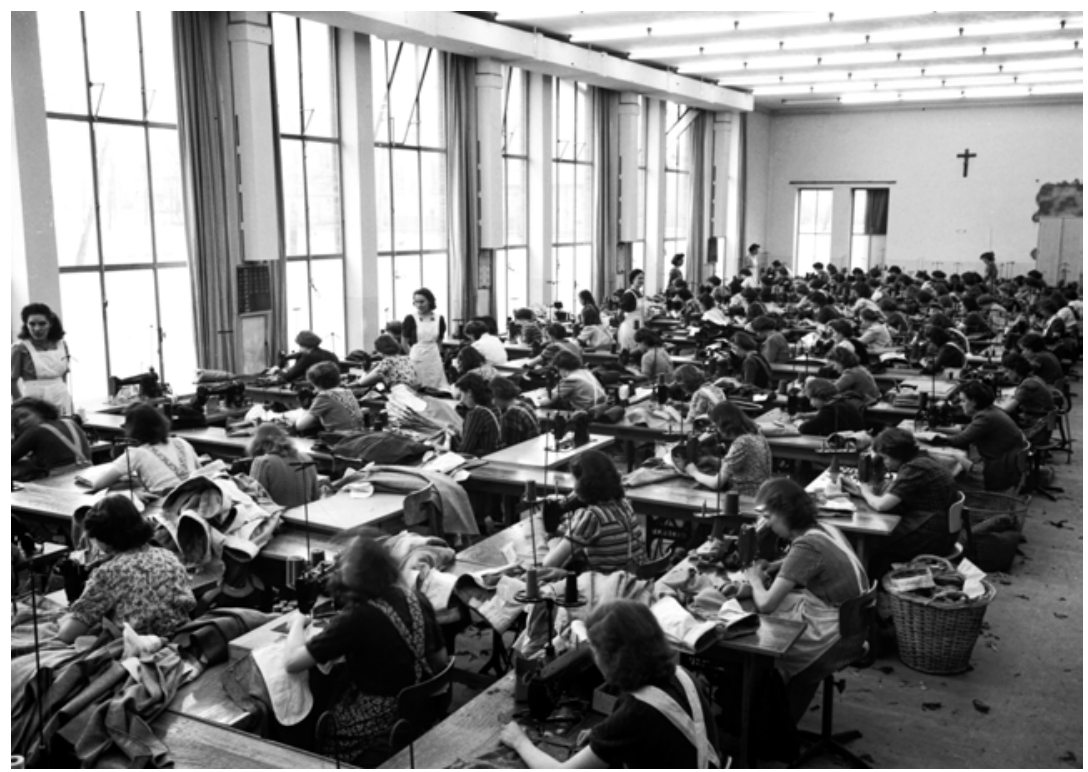

Illustratie 1 De naaizaal van het confectieatelier Lindenheuvel, na 1 januari 1950 onderdeel van Chas Mackintosh, 1951 (bron: RHCL, fotocollectie Staatsmijnen/DSM).

vraag naar werk door vrouwen. Alleen mannen konden profiteren van de groeiende werkgelegenheid in het mijnbedrijf; voor hun vrouwen en dochters was daarin geen plaats. Vrouwen zochten wel mogelijkheden om door arbeid een inkomen te verwerven, maar die waren er eigenlijk alleen voor mijnwerkersdochters omdat de mijnbedrijven speciaal voor hen confectieateliers hadden opgericht. ${ }^{8}$ De eenzijdige arbeidsverdeling in het mijnwerkersgezin op basis van het mannelijke kostwinnersmodel werd dus mede bepaald door de structuur van de lokale arbeidsmarkt. Dit was natuurlijk heel anders in bedrijfstakken en locaties waar wel een grote vraag naar arbeid door vrouwen bestond, zoals in de Maastrichtse aardewerkindustrie of in de textielindustrie.

Belgische geografen hebben deze wat zij noemen 'uneven geography of gender relations' concreet onderzocht door een vergelijking te maken tussen het Belgisch-Limburgse mijnbouwgebied en de textielstad Gent. ${ }^{9}$ Door de verschillende economische structuur was er een groot

8 Vgl. W. Rutten, 'Het thuisfront van de mijnwerker', in: A. Knotter (red.), Mijnwerkers in Limburg. Een sociale geschiedenis (Nijmegen 2012) 388-424, aldaar 417-421.

9 K. Stuyck e.a., 'A geography of gender relations. Role patterns in the context of different regional industrial development', Regional Studies 42 (2008) 69-82. Voor vergelijkbaar onderzoek naar het effect 
contrast in vrouwelijke arbeidsparticipatie: in de jaren 1960 had 35 procent van de potentiële vrouwelijke beroepsbevolking in Gent betaald werk; in Belgisch-Limburg was dat slechts 18 procent. Door de traditionele arbeidsverdeling tussen mannen en vrouwen in de textielindustrie was de keuze voor loonarbeid voor Gentse vrouwen vanzelfsprekend, ook na hun huwelijk. In de gezinnen leidde dat tot een evenwichtiger verdeling van het huishoudelijke werk. In de Belgisch-Limburgse mijncité's daarentegen waren vrouwen op allerlei manieren aan huis gebonden. Net als in Nederlands-Limburg was er in de ruime omtrek geen werk voor vrouwen voorhanden en waren hun inspanningen in het huishouden noodzakelijk om de zware arbeid van mannen in de mijn mogelijk te maken. Zowel door mannen als door vrouwen werd dit ook als een dwingende sociale norm ervaren.

Achter de algemene tendens van dalende vrouwelijke arbeidsparticipatie en de opkomst van het mannelijke kostwinnersmodel konden zich dus grote regionale en lokale verschillen voordoen. In het volgende zal blijken dat dit ook in Limburg het geval was. Limburg wordt hier bestudeerd als casus van de lokale differentiatie, die door Boter voor heel Nederland is vastgesteld.

\section{De economische structuur van Limburg ${ }^{10}$}

Gedurende de hele negentiende eeuw was de landbouw in Limburg de belangrijkste inkomstenbron. In 1849 en 1899 was 44 procent van de beroepsbevolking in deze sector werkzaam. Dat was tien, respectievelijk veertien procentpunt meer dan in Nederland als geheel. Pas ver in de twintigste eeuw ging Limburg in dit opzicht meer in de pas lopen. In 193 o was het aandeel van de agrarische beroepsbevolking in Limburg nog vijf procentpunt hoger, maar in 196o was het ongeveer gelijk met dat in heel Nederland (elf en twaalf procent). Met 32 procent was ook de nijverheid in Limburg in de negentiende eeuw goed vertegenwoordigd, met slechts een enkel procentpunt verschil met Nederland als geheel. Door de opkomst van de mijnindustrie, vooral sinds het begin van de

van verschillende soorten industrieën (waaronder mijnbouw) op arbeid door vrouwen in Engeland zie: V. Hall, Women at work, 1860-1939. How different industries shaped women's experiences (Woodbridge 2013).

10 Ontleend aan A. Knotter, 'De "sociale kwestie". Industrie, arbeid en arbeidsverhoudingen in de negentiende en twintigste eeuw tot circa 1940', in: P. Tummers e.a., Limburg. Een geschiedenis III: vanaf 1800 (Maastricht 2015) 417-445. 
Eerste Wereldoorlog, groeide het aandeel van de industriesector in Limburg in de twintigste eeuw echter veel sterker dan in de rest van het land.

Uit het bekende onderzoek van Jan Winsemius naar de geografische vestigingstendensen van de Nederlandse nijverheid op grond van de beroepstelling van 1930 blijkt dat de aanwezigheid van industrie in Limburg vooral werd bepaald door enerzijds de beschikbaarheid van grondstoffen, met als meest sprekend voorbeeld natuurlijk de mijnindustrie, anderzijds door de aanwezigheid van goedkope arbeid. Die was onder meer bepalend voor de vestiging van de omvangrijke aardewerkindustrie in Maastricht. ${ }^{11}$ Een vergelijkend onderzoek wees in 1939 uit dat de in Maastricht uitbetaalde lonen lager waren dan die in vergelijkbare plaatsen in Nederland. ${ }^{12}$

Anders dan in vele andere arme streken van Nederland had de beschikbaarheid van een goedkoop arbeidsaanbod buiten de steden, op het platteland, niet tot industrievestiging geleid. In verband met de arbeid door vrouwen is het bijvoorbeeld opvallend dat een noemenswaardige textielindustrie, zoals die er wel was in Twente en Noord-Brabant, in Limburg ontbrak. Dat hing waarschijnlijk samen met de omvangrijke seizoenstrek vanuit het Limburgse platteland naar de aangrenzende Duitse gebieden (tot 1914). Daardoor bleef er op het kleine boerenbedrijf geen ruimte voor nevenbedrijven, die de ontstaansgrond hadden gevormd voor de Twentse en Brabantse textielindustrie.

In de volgende paragrafen komt de vraag aan bod wat deze bijzondere economische structuur betekende voor de ontwikkeling van de arbeid door vrouwen in Limburg.

\section{Wat is vrouwelijke arbeidsparticipatie?}

De definitie en de meting van 'vrouwelijke arbeidsparticipatie' zijn helemaal niet vanzelfsprekend. In dit artikel wordt de arbeidsparticipatie van Limburgse vrouwen hoofdzakelijk gemeten aan de hand van beroepstellingen, maar met name waar het gaat om arbeid van vrouwen is het belangrijk om te beseffen dat het hebben van een beroep niet hetzelfde is als het verrichten van arbeid. Een beroep is een identiteit die aan een persoon wordt toegeschreven, door zichzelf of door anderen, anders gezegd: een conventie over welke arbeid als beroep wordt ge-

\footnotetext{
$11 \mathrm{~J}$. Winsemius, Vestigingstendenzen van de Nederlandsche nijverheid (volgens de beroepstelling van 31 december 1930) en de ontwikkeling gedurende het tijdperk 1920-'30 ('s-Gravenhage 1945).

12 Maastricht als vestigingsplaats voor industrie (Maastricht 1939).
} 
waardeerd. Voor arbeid door vrouwen, zeker als die in gezinsverband wordt uitgeoefend, is dat lang niet altijd het geval. Ook arbeid door vrouwen buiten het gezin werd en wordt vaak niet als een 'beroep' beschouwd. Er is daarom consensus onder historici van de vrouwenarbeid dat beroepstellingen en andere vormen van beroepenregistratie de omvang daarvan systematisch onderschatten. ${ }^{13}$

Drie Limburgse voorbeelden uit sectoren die hierna nog uitgebreider aan de orde zullen komen, illustreren dit: de Maastrichtse aardewerkindustrie, de landbouw en de mijnbouw. In zijn dissertatie over het Boschstraatkwartier in Maastricht kon Thijs van Vugt de beroepsvermeldingen van bij de glas- en aardewerkfabrieken van de Sphinx werkzame vrouwen in het bevolkingsregister systematisch vergelijken met die in de personeelsadministratie van het bedrijf. Van 417 van de 455 vrouwen die per 1 januari 188 o stonden ingeschreven in het personeelsregister werd geen beroep vermeld in het bevolkingsregister, dat is 92 procent; in 1905 was dat het geval bij 186 van de 253 bij Sphinx werkzame vrouwen, dat is 74 procent. ${ }^{14} \mathrm{Nu}$ gaat het hier om beroepsvermeldingen in het bevolkingsregister en niet om een beroepstelling, maar deze verschillen geven wel aan hoe weinig deze arbeid door registrerende gemeenteambtenaren, en mogelijk ook door deze vrouwen zelf, daadwerkelijk als een beroep werd beschouwd.

Een tweede voorbeeld betreft de door vrouwen verrichte arbeid in de landbouw in het Noord-Limburgse landbouwdorp Horst in de jaren $1950 .{ }^{15}$ In de beroepstelling van 1960 werden in die gemeente 83 in de landbouw werkende vrouwen geteld, maar uit een in 1955 gehouden arbeidsenquête bleek dat alleen al 369 van de 548 ondervraagde boerendochters thuis een vorm van agrarische arbeid verrichtten, meestal in combinatie met huishoudelijke werkzaamheden. De landbouwtelling van 1956 meldde 808 meewerkende vrouwelijke gezinsleden in de landbouw in Horst, ook in dit geval grotendeels part time naast werk in

13 J. Humphries en C. Sarasúa, 'Off the Record. Reconstructing women's labor force participation in the European past', Feminist Economics 18:4 (2012) 39-67. Voor Nederland: Schmidt en Van Nederveen Meerkerk, 'Reconsidering The "First Male-Breadwinner Economy" ', 79-89; C. van Eijl, Hetwerkzame verschil. Vrouwen in de slag om arbeid 1 898-1940 (Hilversum 1994) 39-46, met verschillende voorbeelden van ondertelling in de beroepstellingen.

14 T. van Vugt, Een arbeidersbuurt onder de rook van 'De Sphinx.' Een sociaal-ruimtelijke geschiedenis van het Boschstraatkwartier-Oost te Maastricht (Hilversum 2015) 83 .

15 Ontleend aan E. Jacobs, 'De arbeid van ongehuwde vrouwen in mijnwerkers- en boerengezinnen. Een onderzoek in de Limburgse gemeenten Stein en Horst in de jaren 1950', Studies over de sociaaleconomische geschiedenis van Limburg/Jaarboek van het Sociaal Historisch Centrum voor Limburg LXII (2017) 76-10o, aldaar 85-91. 
het huishouden. Door deze arbeid leverden deze vrouwen in economische zin wel degelijk een belangrijke bijdrage aan het reilen en zeilen van het gezinsbedrijf, maar zij werden niet als werkzaam in de landbouw opgenomen in de beroepstelling van 1960.

Het derde voorbeeld betreft de mijnindustrie. In deze sector bestond een zeer strikte scheiding tussen loonarbeid door de mannelijke gezinsleden in de mijn en huishoudelijke arbeid door de vrouwen in het gezin. ${ }^{16}$ Die was volledig gewijd aan de zorg voor het huishouden en alles wat nodig was om het de mannen mogelijk te maken hun zware en onregelmatige arbeid in de mijn te verrichten. Het huishouden moest worden aangepast aan de wisselende diensten van de man en de werkende zoons. Het koken op verschillende tijden, het wassen van de mijnkleding en het opvoeden van de kinderen vereisten een voortdurende en flexibele arbeidsinzet van de mijnwerkersvrouw, waar mogelijk ondersteund door opgroeiende dochters. De mijnwerkersvrouwen werkten zich zogezegd uit de naad, maar hun arbeid werd niet als beroep herkend en benoemd.

Ondanks deze tekortkomingen zullen in wat volgt tellingen van beroepen in de officiële beroepstellingen centraal staan. Waar mogelijk worden de gegevens uit de beroepstellingen kritisch onder de loep genomen, maar er zijn nu eenmaal weinig andere betrouwbare en systematische bronnen over arbeid.

\section{De evolutie van de vrouwenarbeid in Limburg}

Voor velen is het misschien een verrassing dat de vrouwelijke arbeidsparticipatie in Limburg in de loop van de twintigste eeuw is geëvolueerd van een relatief hoog naar een relatief laag niveau - relatief wil in dit verband zeggen: in vergelijking met Nederland als geheel. ${ }^{17}$ Het verschil is zichtbaar in grafiek 1 . Daaruit blijkt, ten eerste, dat er tot halverwege de twintigste eeuw naar verhouding meer vrouwen in Limburg een beroep uitoefenden dan in Nederland als geheel, ten tweede, dat deze Limburgse voorsprong in de eerste helft van de twintigste eeuw geleidelijk daalde om, ten derde, in de jaren 1950 om te slaan in een 
Grafiek 1 Het verschil in vrouwelijke arbeidsparticipatie in Limburg en Nederland, 1889-1991 (procentpunten)

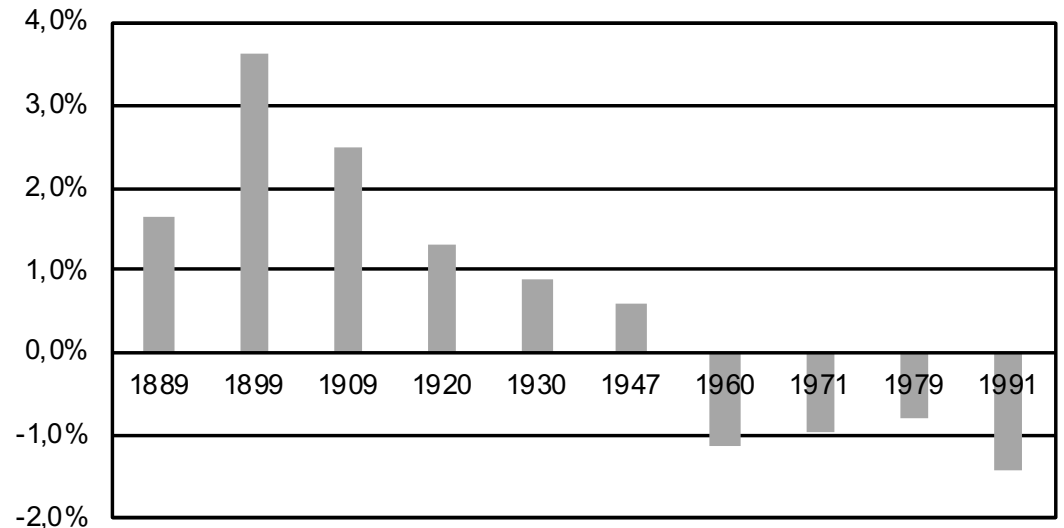

Bronnen: Beroepstellingen 1889-1971; CBS, Regionaal statistisch zakboek, 1982 en 1993.

achterstand..$^{18}$ Vandaar dat in de titel van dit artikel sprake is van een 'stille revolutie'. Die revolutie wordt hier nader geanalyseerd door in te zoomen op specifieke beroepscategorieën en lokale verschillen.

Als eerste stap in de verklaring voor de relatief hoge vrouwelijke arbeidsparticipatie in Limburg is de vrouwelijke beroepsbevolking uitgesplitst naar economische sector en vergeleken met die in Nederland als geheel (grafiek 2). Daaruit blijkt dat die gedurende de gehele periode van overwicht, dus tot en met de telling van 1947, grotendeels kan worden toegeschreven aan het werk van vrouwen in de landbouwsector. Tot in het begin van de twintigste eeuw waren vrouwen in Limburg ook oververtegenwoordigd in de industrie, maar in de beroepstellingen na die van 1909, met name die in de jaren 1920, 1930 en 1940, waren er naar verhouding juist minder Limburgse vrouwen werkzaam in de industrie. Dat is een gevolg van het grote belang van de mijnbouw in die periode, waarin vrijwel geen vrouwen werkten. De dienstensector is wat betreft de deelname van vrouwen gedurende de gehele periode ondervertegenwoordigd in Limburg. Hieronder zal blijken dat deze verschillen per sector ook zichtbaar zijn in een grote regionale verscheidenheid in vrouwelijke arbeidsparticipatie in Limburg (althans tot de jaren 1950): hoog in de landbouwdorpen en in de Maastrichtse industrie, laag in de mijnbouwgebieden.

18 In deze en alle hierna volgende berekeningen op basis van de beroepstellingen wordt 'vrouwelijke arbeidsparticipatie' gedefinieerd als het aantal vrouwen met een geteld beroep ten opzichte van de totale vrouwelijke bevolking. 


\section{Grafiek 2 Het verschil in vrouwelijke arbeidsparticipatie in Limburg en Nederland per sector, 1889-1971 (procentpunten)}

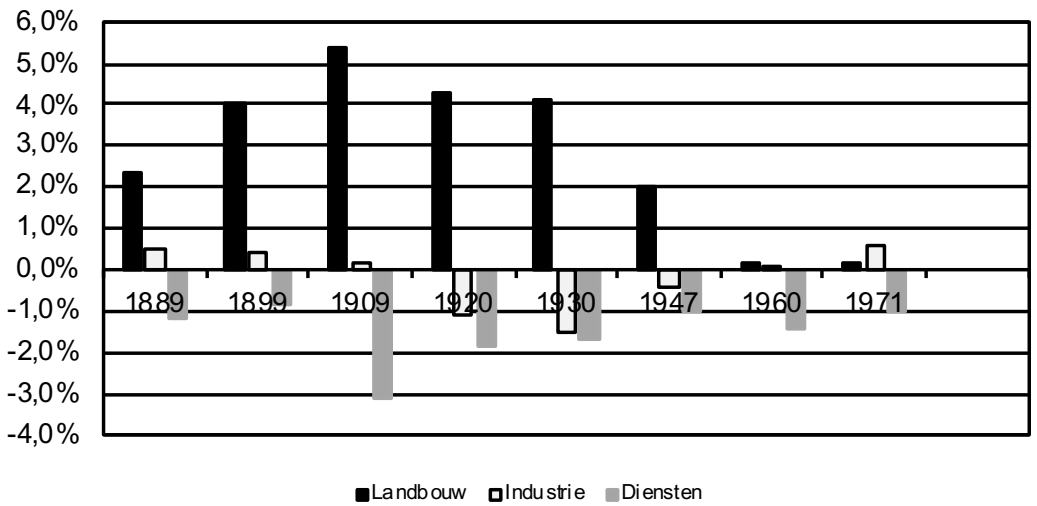

Bronnen: Beroepstellingen 1889-1971.

\section{Het regionale patroon in 1909}

Om de naar verhouding hoge vrouwelijke arbeidsparticipatie in Limburg tot het midden van de vorige eeuw en de omslag daarna te verklaren, is het onderzoek toegespitst op een aantal geselecteerde subregio's met een eigen economische structuur. Als uitgangspunt zijn de verhoudingen per gemeente genomen in het begin van de twintigste eeuw, op basis van de beroepstelling van $1909 .{ }^{19} \mathrm{Om}$ de regionale verschillen in vrouwelijke arbeidsparticipatie in Limburg in kaart te brengen zijn de gegevens per gemeente in 1909 allereerst ingedeeld in economisch-geografische gebieden volgens de standaard-indeling van het Centraal Bu-

19 Centraal Bureau voor de Statistiek, Uitkomsten der beroepstelling in het Koninkrijk der Nederlanden gehouden op den een en dertigsten december 1909. Eerste deel. Overzicht voor iedere gemeente van Nederland van de voornaamste beroepen, die in de gemeente worden uitgeoefend [...] [Bijdragen tot de statistiek van Nederland, nieuwe volgreeks No. CLXVII] ('s-Gravenhage 1912). Behalve door de beschikbaarheid van gegevens per gemeente in deze telling, is de keuze daarvoor mede ingegeven door de veronderstelde grotere betrouwbaarheid wat betreft de vrouwelijke arbeidsparticipatie in de landbouw in vergelijking met de negentiende-eeuwse tellingen, met name wat betreft de inzet van vrouwelijke gezinsleden in het gezinsbedrijf. Vgl. J.L. van Zanden, De economische ontwikkeling van de Nederlandse landbouw in de negentiende eeuw 1800-1914 (Utrecht 1985) 68-69, en Engelen en Kalkman, 'Vrouwenarbeid en zijn demografische achtergronden', 3o6-308. Zie voor de onderregistratie van werkende vrouwen in de landbouw in de negentiende-eeuwse tellingen ook E. van Nederveen Meerkerk en R. Paping, 'Beyond the census. Reconstructing Dutch women's labour market participation in agriculture in the Netherlands, ca. 1830-1910', The History of the Family 19 (2014) 447-468. 
reau voor de Statistiek (CBS) uit 1961 (zie kaart 1). ${ }^{20}$ Opvallend is de hoge arbeidsparticipatie van vrouwen (tussen de 25 en 27 procent) in de landbouwstreken in Midden-Limburg en het Heuvelland. Dit hoge percentage is direct gerelateerd aan de arbeid van vrouwen in de landbouw. In het gebied ten westen van de Maas tussen Roermond en Weert was zelfs twee-derde van de vrouwen met een beroep in de landbouw werkzaam. Hoge percentages vrouwen in de landbouw komen ook voor in het Heuvelland en in de latere Westelijke Mijnstreek. In 1909 was daar nog geen mijnbouw - die zou er pas komen na de opening van de mijn Maurits in Geleen in 1925. ${ }^{21}$ Daardoor was de landbouw daar in 1909 nog belangrijk en de vrouwelijke arbeidsparticipatie nog relatief hoog, namelijk 23 procent tegen 22 procent in de provincie als geheel. In de Oostelijke Mijnstreek, waar de mijnindustrie vanaf het begin van de eeuw sterk opkwam, is het aandeel van vrouwen met een beroep volgens verwachting wel een stuk lager dan het Limburgse gemiddelde (17 procent). Daar was ook het aandeel van vrouwen in de landbouw beperkt.

De uitkomsten van deze regionale vergelijking per economisch-geografisch gebied waren aanleiding in te zoomen op een aantal geselecteerde gemeenten binnen deze gebieden, die representatief kunnen worden geacht voor de arbeid door vrouwen - of het ontbreken daarvan - in de landbouw, de Maastrichtse industrie en de mijnbouw (zie kaart 2). ${ }^{22}$ Het betreft in de eerste plaats een tweetal clusters van landbouwdorpen met in 1909 de hoogste vrouwelijke arbeidsparticipatie in Midden-Limburg tussen Roermond en Weert en in het Heuvelland ten oosten van Maastricht. ${ }^{23}$ In de tweede plaats wordt ingezoomd op

20 Vgl. R. van der Bie, De economisch-geografische indelingen van het cbs, 1917-1960 (Den Haag/Heerlen 2009). De indeling van de Limburgse gemeenten in economisch-geografische gebieden is ontleend aan S. Langeweg, Mijnbouw en arbeidsmarkt in Nederlands-Limburg. Herkomst, werving, mobiliteit en binding van mijnwerkers tussen 1900 en 1965 (Hilversum 2011) 286-287. Ik dank Thijs van Vugt voor zijn hulp bij het maken van de kaarten.

21 Vgl. A. Knotter, 'The miners of Geulle. Mining and rural transformation in Limburg (the Netherlands), 1900-1940', in: P. Puschmann en T. Riswick (red.), Building bridges. Scholars, history and historical demography. A festschrift in honor of professor Theo Engelen (Nijmegen 2018) 285-310.

22 Bronnen: 1909: CBS, Uitkomsten der Beroepstelling [...] 1909; 1930: SHCL, archief Economisch-Technologisch Instituut in Limburg (ETIL), inv. nrs. 923-926: Staten van CBS-gegevens over de bevolking per Limburgse gemeente [1930 en 1947]; 1947-1971: SHCL: Collectie CBS-statistieken, BH 1.1: Uitkomsten van de volks- en beroepstelling 31 mei 1947 per gemeente van de provincie Limburg; BH 1.2: Uitkomsten van de $13^{\mathrm{e}}$ algemene volkstelling, 31 mei 196o, deel 6: Limburg; Bн 1.3: $14^{\mathrm{e}}$ algemene volkstelling annex woningtelling 28 februari 1971: definitieve uitkomsten per Limburgse gemeente.

23 Midden-Limburg: Baexem, Grathem, Heythuysen, Hunsel, Meijel, Roggel, Stramproy, Beegden, Haelen, Heel en Panheel, Horn, Neer, Thorn, Wessem; Heuvelland: Bemelen, Berg en Terblijt, Cadier en Keer, St.-Geertruid, Gronsveld, Margraten, Mheer, Noorbeek, Slenaken. 
Kaart 1 Percentage vrouwen met beroep in de Limburgse economisch-geografische gebieden in 1909

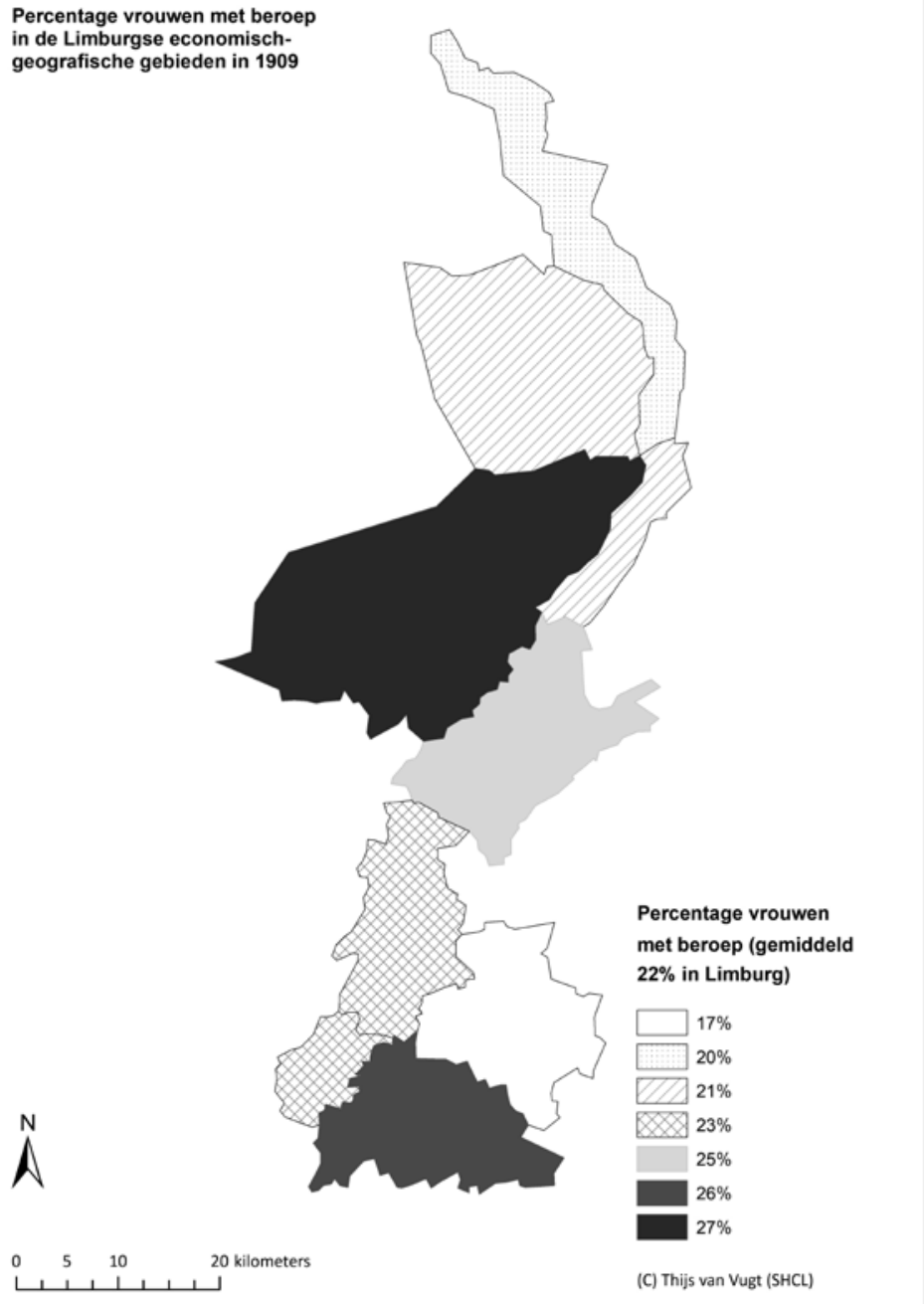

(c) Thijs van Vugt, SHCL 
Kaart 2 Percentage vrouwen met beroep in clusters van geselecteerde Limburgse gemeenten in 1909 (landbouwdorpen, mijngemeenten, Maastricht)

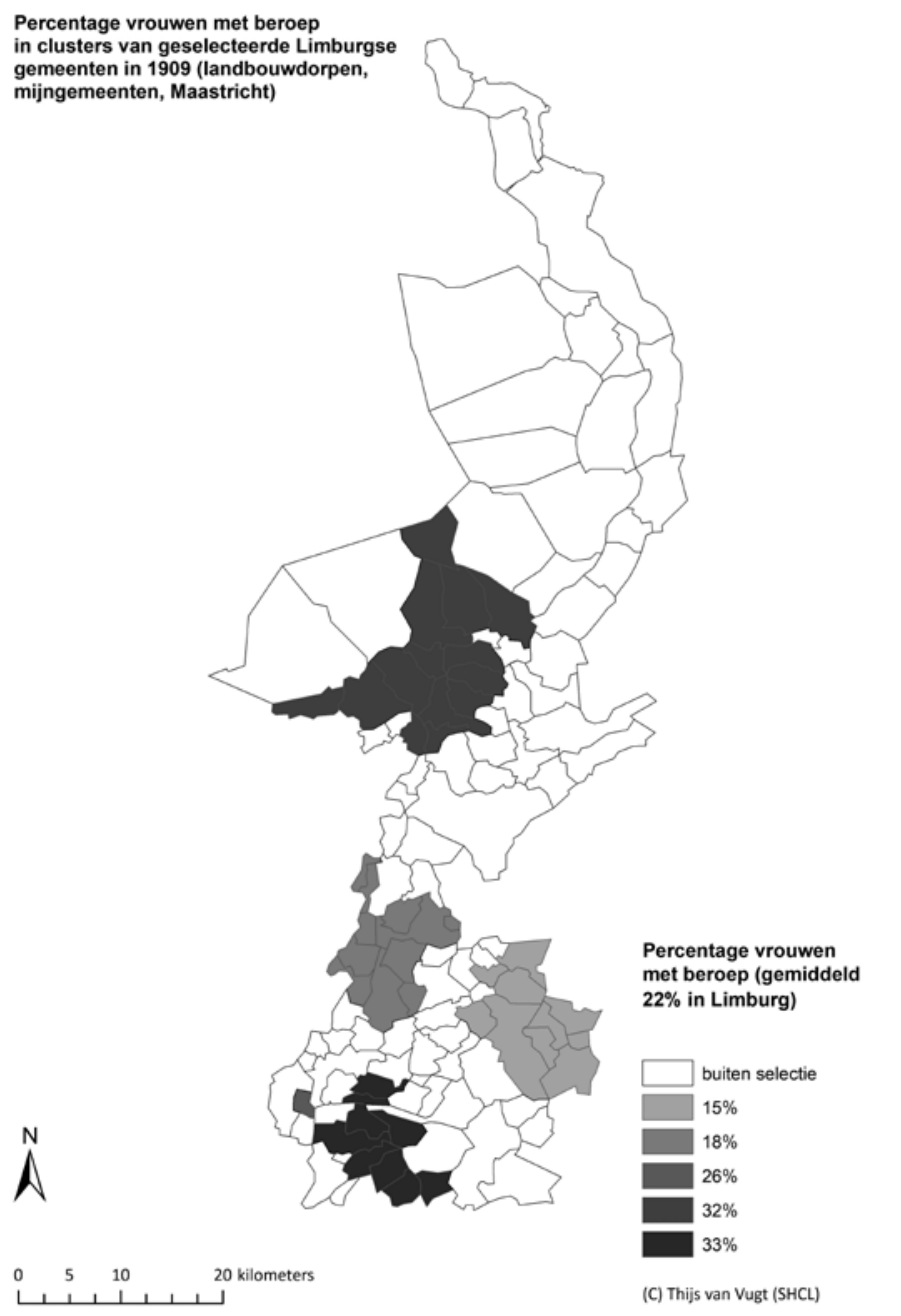

(c) Thijs van Vugt, SHCL 
de stad Maastricht zelf, en in de derde plaats op de typische mijngemeenten in de Oostelijke en Westelijke Mijnstreken. ${ }^{24}$ De keuze voor deze specifieke gemeenten doet de onder- en oververtegenwoordiging van vrouwen in de beroepsbevolking in 1909 des te scherper uitkomen. In de clustering komen de Midden-Limburgse landbouwdorpen ongeveer gelijk uit met die in het Heuvelland, namelijk respectievelijk 32 en 33 procent, dat is 5 tot 6 procentpunten hoger dan in het omliggende economisch-geografische gebied. De vrouwelijke arbeidsdeelname in alleen de stad Maastricht komt 3 procentpunt hoger uit dan in het economisch-geografische gebied inclusief de omliggende dorpen ( 26 tegen 23 procent), een bewijs dat die vooral werd bepaald door de vrouwenarbeid in de Maastrichtse industrie. In de specifieke mijngemeenten werkten volgens verwachting relatief weinig vrouwen met een beroep.

\section{Vrouwen en arbeid per sector en regio, 1909-1971: mijn- bouw, landbouw, Maastricht}

Om de ontwikkeling van de vrouwelijke arbeidsparticipatie in Limburg in de loop van de twintigste eeuw nader te kunnen analyseren, zijn de op basis van de telling van 1909 gevormde clusters van landbouwdorpen, mijngemeenten en de stad Maastricht ook aangehouden voor een berekening van het percentage vrouwen met een beroep in deze clusters in de beroepstellingen van 1930, 1947, 1960 en 1971. Om deze cijfers beter inzichtelijk te maken zijn de percentages weergegeven in een grafische voorstelling van de ontwikkeling in elk van de drie categorieën, steeds in vergelijking met het Limburgse gemiddelde (grafieken 3-5).

De ontwikkeling in elk van deze categorieën laat opmerkelijke verschillen zien. In de mijngemeenten lag de vrouwelijke arbeidsparticipatie gedurende de gehele periode onder het Limburgse gemiddelde, met een dieptepunt in 1930. Daarna nam die ook in verhouding tot Limburg als geheel weer wat toe om in 1971 uit te komen op ongeveer hetzelfde niveau als het Limburgse gemiddelde. In de landbouwdorpen bleef de vrouwelijke arbeidsdeelneming gedurende de gehele eerste helft van de twintigste eeuw op een relatief hoog niveau (met een lichte daling). Pas in de jaren tussen de telling van 1947 en 1960 nam die in korte tijd substantieel af tot het niveau van het Limburgse gemiddelde. Uit de gege-

24 Oostelijke Mijnstreek: Brunssum, Eygelshoven, Heerlen, Hoensbroek, Kerkrade, Merkelbeek, Nieuwenhagen, Schaesberg, Schinveld, Ubach over Worms; Westelijke Mijnstreek: Beek, Elsloo, Geleen, Grevenbicht, Limbricht, Obbicht en Papenhoven, Sittard, Spaubeek, Stein, Urmond, Broeksittard. 
Grafieken 3-5 Het percentage vrouwen met een beroep in de mijngemeenten in de Oostelijke en Westelijke Mijnstreken, in landbouwdorpen in Midden-Limburg en het Heuvelland, en in Maastricht, 1909-1971
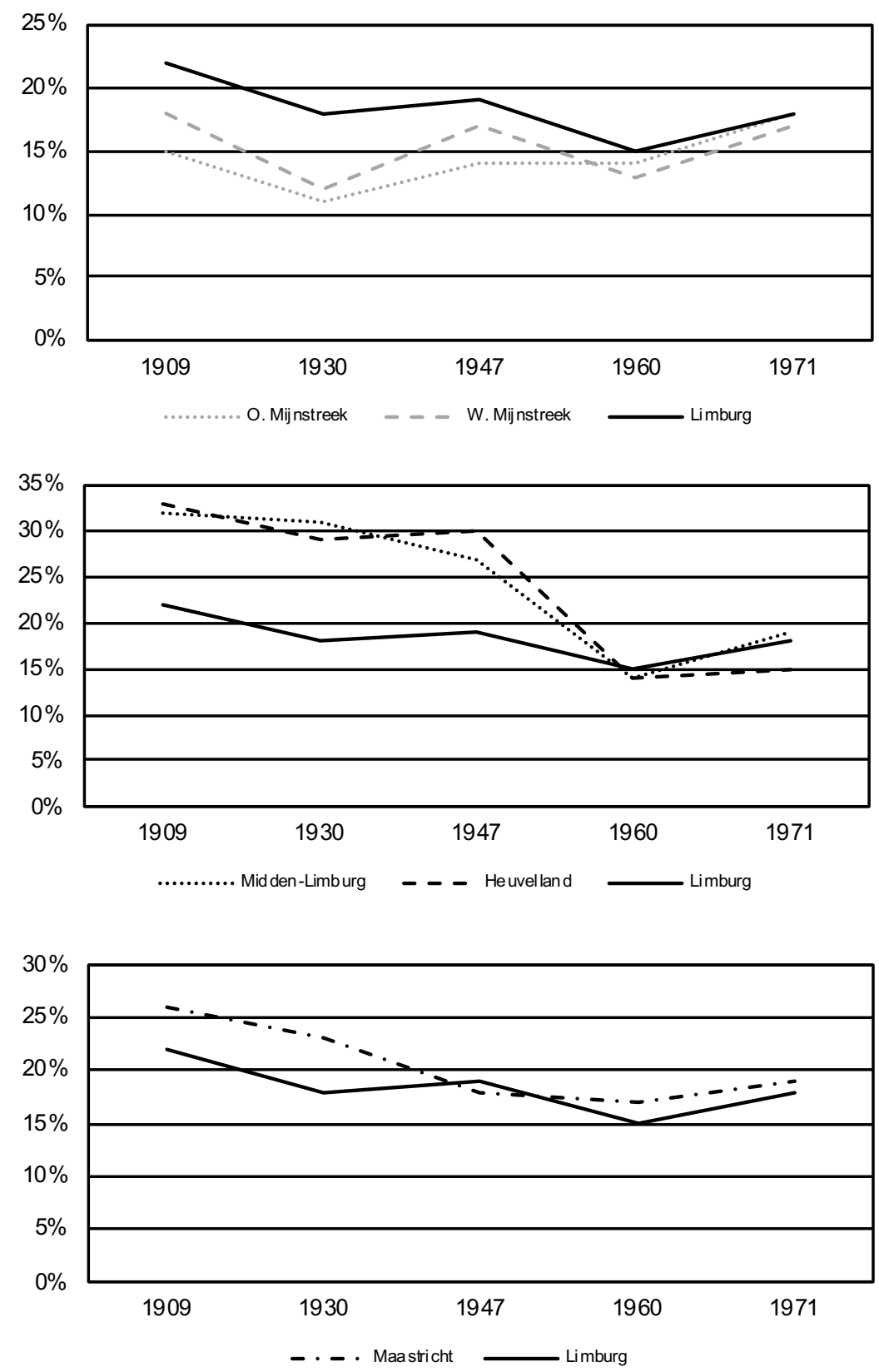
vens van deze beroepstellingen zou dus kunnen worden afgeleid dat er in de jaren 1950 in Limburg een ware omwenteling heeft plaatsgevonden in de agrarische arbeidsverdeling tussen mannen en vrouwen. In wat volgt zal echter blijken dat deze uitkomst in het licht van andere tellingen aanzienlijk moet worden genuanceerd. In Maastricht daalde het aandeel van werkende vrouwen van betrekkelijk hoog in 1909 tot onder het Limburgse gemiddelde in de telling van 1947. Hieronder wordt de ontwikkeling per bedrijfstak en regio nader onderzocht.

\section{Beroepsarbeid van vrouwen in de mijngemeenten}

De opkomst van de mijnindustrie in de mijngemeenten was in 1930 min of meer voltooid. In de Oostelijke Mijnstreek was er toen nog nauwelijks werkgelegenheid voor vrouwen in de landbouw. In de mijngemeenten in de Westelijke Mijnstreek was dat nog wel het geval: daar verdween die pas in de jaren 1950. Het grootste deel van de vrouwen in de mijnstreken werkte in de dienstensector, maar het aandeel daarvan nam wel af, vooral door de achteruitgang van het aandeel van dienstboden en andere huiselijk diensten in zowel de Oostelijke als de Westelijke Mijnstreek van respectievelijk 31 en 28 procent van de vrouwelijke beroepsbevolking in 1930 naar 9 en 10 procent in 196o. Met de groei van de bevolking in de mijngemeenten en van de koopkracht van de mijnwerkersgezinnen werd het werk van vrouwen in de dienstensector gevarieerder, onder meer door de toename van werk in de detailhandel, en dat gold ook voor de naar verhouding sterk groeiende vrouwelijke werkgelegenheid in de industrie. In 1930 was die in de mijngemeenten in de Oostelijke en Westelijke Mijnstreken nog grotendeels beperkt tot de kledingsector: daarin werkten toen respectievelijk 81 en 77 procent van de vrouwen in de nijverheid. In 1947 was dit percentage gedaald tot $5^{8}$ en $5^{2}$, en in 1960 tot 43 en 35 procent. ${ }^{25}$ In grafiek 3 is vastgesteld dat de vrouwelijke arbeidsparticipatie in de mijngemeenten na een dieptepunt in 1930 weer begon te groeien, en tabel 1 laat zien dat het aandeel van vrouwen in de industrie naar verhouding het meeste toenam. Dit suggereert dat er een zekere diversificatie van industriële werkgelegenheid voor vrouwen heeft plaatsgevonden die positief uitwerkte voor de vrouwelijke arbeidsparticipatie. 
Tabel 1 De vrouwelijke beroepsbevolking naar sector in de mijngemeenten in de Oostelijke en Westelijke Mijnstreken, 1930-1960

\begin{tabular}{|l|c|c|c|c|}
\hline Mijngemeenten & Industrie & Landbouw & Diensten & N= \\
\hline Oostelijke Mijnstreek & & & & \\
\hline 1930 & $14 \%$ & $5 \%$ & $81 \%$ & 7.525 \\
\hline 1947 & $27 \%$ & $5 \%$ & $68 \%$ & 11.649 \\
\hline 1960 & $31 \%$ & $0 \%$ & $69 \%$ & 14.313 \\
\hline Westelijke Mijnstreek & & & & \\
\hline 1930 & $11 \%$ & $18 \%$ & $71 \%$ & 2.826 \\
\hline 1947 & $18 \%$ & $20 \%$ & $62 \%$ & 5.392 \\
\hline 1960 & $29 \%$ & $2 \%$ & $68 \%$ & 6.395 \\
\hline
\end{tabular}

Voor de selectie van mijngemeenten: zie noot 24.

Bronnen: zie noot 22.

Dat neemt niet weg dat de kledingindustrie een belangrijk aandeel bleef houden in werkgelegenheid van met name mijnwerkersdochters. In de jaren 1930 nam Staatsmijnen het initiatief voor de oprichting van confectieateliers in Treebeek, Lutterade en Terwinselen, speciaal voor meisjes uit mijnwerkersgezinnen. Ook particuliere ondernemers vestigden tricotage- en confectiefabrieken in Zuid-Limburg. Na de oorlog breidde deze industrie zich verder uit: in 1966 waren er 33 confectiebedrijven in de mijnstreek gevestigd, waarin ongeveer 3.300 vrouwen en 1.100 mannen werkten. ${ }^{26}$ De industrie bood vooral werk aan jonge ongehuwde vrouwen uit mijnwerkersgezinnen. Dat weerspiegelt zich duidelijk in de leeftijdsopbouw van de vrouwen in de kledingsector in de mijngemeenten in de beroepstellingen van 1947 en 1971 (tabel 2). In 1947 was het percentage vrouwen in de kledingindustrie jonger dan 25 jaar in de mijngemeenten in de Oostelijke Mijnstreek en Westelijke Mijnstreken respectievelijk 17 en 19 procentpunten hoger dan in de vrouwelijke beroepsbevolking als geheel. In 1971 waren deze verhoudingen in de Oostelijke Mijnstreek niet veranderd; in de Westelijke Mijnstreek was het aandeel van jonge vrouwen en meisjes zelfs nog toegenomen. 
Tabel 2 Aandeel jonge vrouwen werkzaam in de kledingsector in de mijngemeenten in de Oostelijke en Westelijke Mijnstreken, 1947 en 1971

\begin{tabular}{l|c|c|}
\hline & $\begin{array}{c}\text { Vrouwen t/m 24 jaar } \\
\text { in de kledingindustrie }\end{array}$ & $\begin{array}{c}\text { Vrouwen t/m 24 jaar } \\
\text { in de beroepsbevolking }\end{array}$ \\
\hline 1947 & & \\
\hline Oostelijke Mijnstreek & $74 \%$ & $57 \%$ \\
\hline Westelijke Mijnstreek & $67 \%$ & $48 \%$ \\
\hline 1971 & & \\
\hline Oostelijke Mijnstreek & $74 \%$ & $51 \%$ \\
\hline Westelijke Mijnstreek & $82 \%$ & $56 \%$ \\
\hline
\end{tabular}

Voor de selectie van mijngemeenten: zie noot 24.

Bron: SHCL: Collectie CBS-statistieken, BH 1.1: Uitkomsten van de volks- en beroepstelling 31 mei 1947 per gemeente van de provincie Limburg; $\mathrm{BH}$ 1.3: 14e algemene volkstelling annex woningtelling 28 februari 1971: definitieve uitkomsten per Limburgse gemeente.

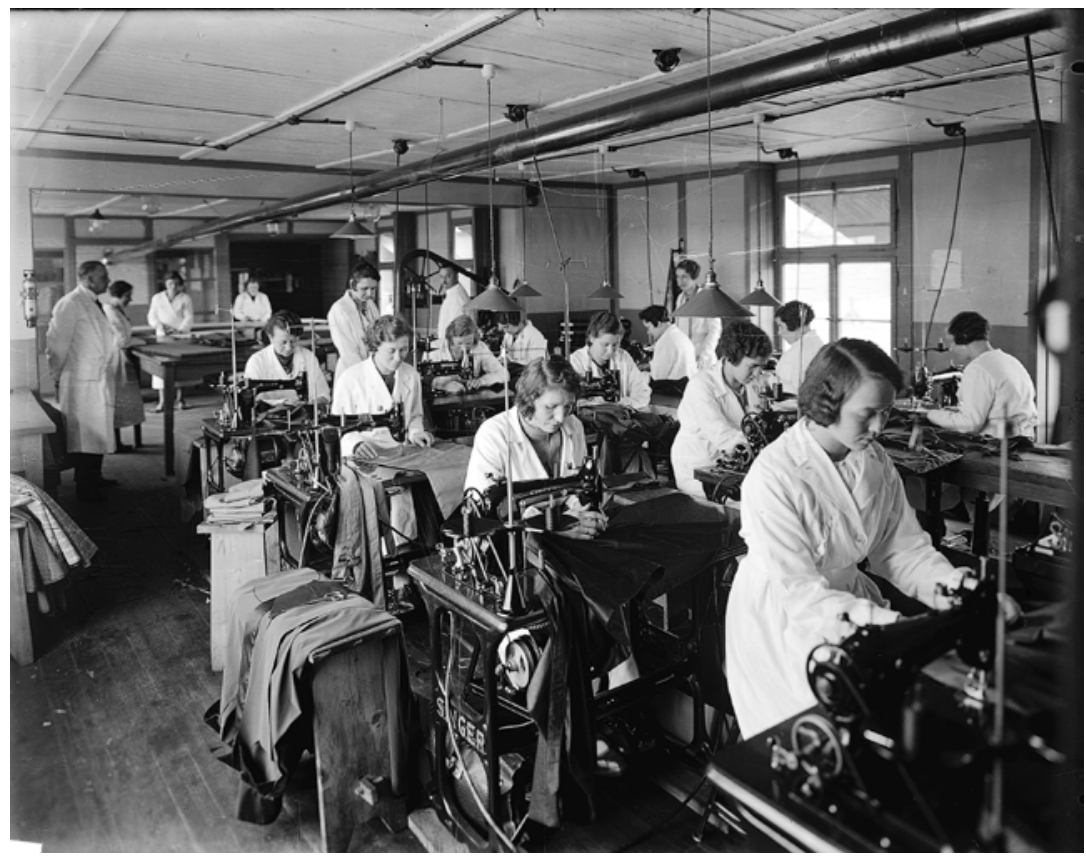

Illustratie 2 Het Fonds voor Sociale Instellingen van Staatsmijnen opende begin jaren 1930 enkele confectieateliers voor mijnwerkersdochters. Hier een kijkje in het atelier voor regenkleding in Terwinselen, 1936 (bron: RHCL, fotocollectie Staatsmijnen/ DSM). 
Onder deze jonge confectiewerksters vonden volgens een onderzoek van vlak vóór de Tweede Wereldoorlog 'abnormaal hooge personeelswisselingen' plaats, die 'ten nauwste samenhingen met de milieus waaruit de meisjes afkomstig zijn'. ${ }^{27}$ Verreweg de meeste kwamen uit mijnwerkersgezinnen en deze categorie 'treedt meestal vroegtijdig in het huwelijk en bovendien vormt haar loon slechts een betrekkelijk geringe en veelal niet noodzakelijke aanvulling van het gezinsinkomen. Vandaar dat er geen dwingende redenen voor deze vrouwen zijn om zeer lang in dienst te blijven'. De algemene tendens van een marginale arbeidsparticipatie van vrouwen in de mijnstreek werd dus door de vestiging van deze industrie niet opgeheven.

\section{Vrouwenarbeid in de landbouw}

In het gedenkboek bij het vijfentwintigjarig bestaan van de Limburgse Boerinnenbond in 1955 gaf auteur W.J. Vromen een overzicht van het werk van de boerin en haar dochters in - zoals hij het noemt - 'de oude tijd', zo'n vijftig jaar eerder. ${ }^{28} \mathrm{Er}$ was werk voor vrouwen in de teelt, de oogst en het vervoer van veevoer, het wieden van onkruid en bij de graanoogst, met name het binden van de schoven. De zorg voor het vee, koeien, varkens en pluimvee behoorde eveneens tot het domein van de vrouw, evenals de zuivelbereiding, zowel het melken als de boter- en kaasbereiding. De huishouding omvatte naast 'gewone' dagelijkse werkzaamheden zoals koken en schoonmaken, ook de teelt van groente en fruit voor eigen gebruik, inclusief het inmaken daarvan.

Interviews met in die tijd geboren boerinnen vertellen hetzelfde verhaal, zoals dat van een in 1908 geboren boerin uit Herten (bij Roermond):

Voordat ik zes jaar, was deed ik al werkjes op de boerderij. Met de koeien langs de weg zitten [...]. Het duurde een paar uur voordat ze volgegeten waren. [...] Melken en de stal leegmaken deden we vanaf dat we tien, twaalf jaar waren. Als je tien was, moest er 'duchtig' gewerkt worden. Overal aanpakken, op het veld, met het vee, hooien, aardappelen rapen, de 'hele smeer'. [...] We moesten mee naar het veld, schoven binden, met de zig maaien. ${ }^{29}$

27 J.J.J. van de Venne, 'De tricotage- en confectie-industrie in de mijnstreek', Economisch-Statistische Berichten 29 (1944) 64-68.

28 W.J. Vromen, 25 jaar boerinnenbond in Limburg (z.p. 1955) 13-37.

29 Geciteerd door Margit van der Steen, “'Ich bun altied un stjerk vroumus gewaes”. Leven en werken van een boerin in een Midden-Limburgse plattelandsgemeenschap, Herten 1910-1960', Studies over de 


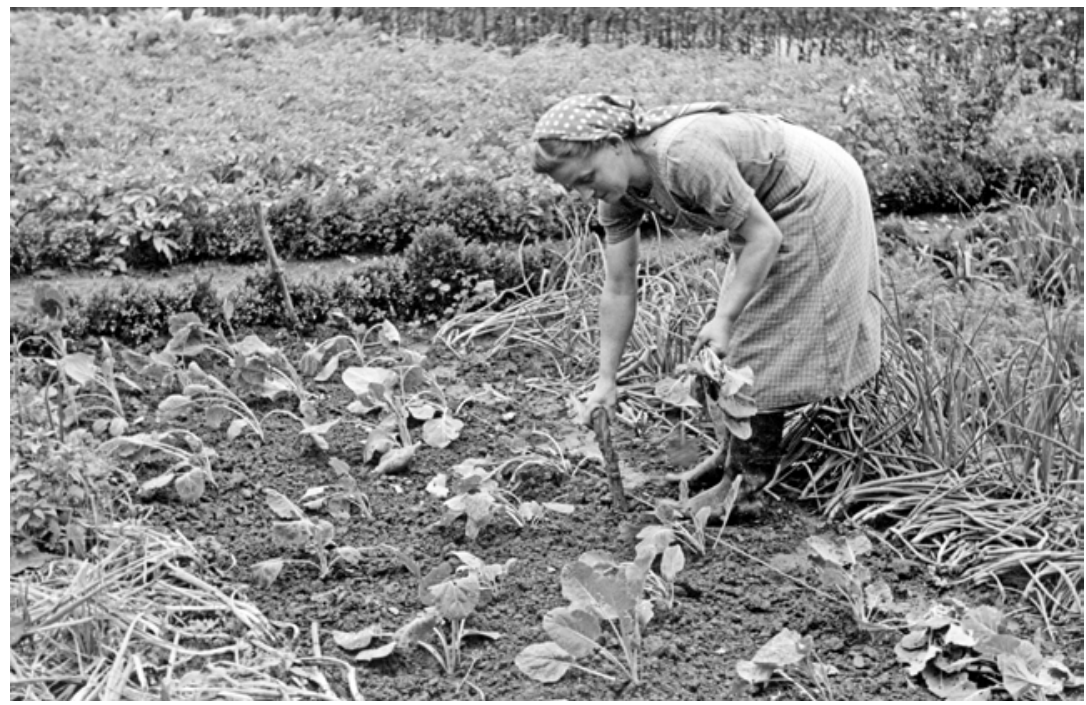

Illustratie 3 Een boerin plat jonge spruitkoolplantjes in de moestuin, ca. 1960 (bron: SHCL, fotocollectie Zij-Actief).

Eenmaal getrouwd, moest zij het werk voor het bedrijf combineren met het werk in de huishouding. Ook dat laatste was arbeidsintensief, onder meer omdat de boerin zorg moest dragen voor de voedselvoorziening van haar gezin uit eigen stal en tuin..$^{30}$

Landbouwenquêtes uit het eind van de negentiende en het begin van de twintigste eeuw bevestigen dat beeld..$^{31}$ Van groot belang voor de inzet van vrouwelijke gezinsleden in het landbouwbedrijf was de groei en de toenemende intensiteit van de arbeid op het kleinbedrijf. In 1912 werd in een onderzoeksrapport over de landbouw in Limburg gesteld: 'Ontegenzeggelijk zijn de kleinere bedrijven in intensiteit het sterkst vooruitgegaan, vooral omdat het werk hier kan geschieden met eigen

sociaaleconomische geschiedenis van Limburg/Jaarboekvan het Sociaal Historisch Centrum voor Limburg XLVII (2002) 137-155, aldaar 142.

3o Ibidem, 151-153; zie ook A. Gielen-Van Bommel, “"Niks doen was er niet bij”. Het leven van een boerin en haar dochters in Horst aan het begin van deze eeuw', in: G.F. Verheijen e.a. (red.), Horster Historiën 3. Van boeren en ondernemers (Horst 1992) 203-226.

31 Uitkomsten van het onderzoek naar den toestand van den Landbouw in Nederland, ingesteld door de Landbouwcommissie, benoemd bij Koninklijk Besluit van 18 september 1886, No. 28. Derde Deel ('s-Gravenhage 189o) LXXXVIII, 11; Staatscommissie voor den landbouw ingesteld bij K.B. van 20 juni 1906, No. 72, Verslagen betreffende den Oeconomischen toestand der landarbeiders in Nederland II: Utrecht-Limburg ('s-Gravenhage 1908) 361. C. Bulden, 'Schets van de ontwikkeling van het landbouwbedrijf op de löss-gronden van Zuid-Limburg (ten zuiden van Susteren)', in: Staatscommissie voor den landbouw ingesteld bij K.B. van 20 juni 1906, No. 72, Schetsen van het landbouwbedrijf in Nederland ('s-Gravenhage 1912) 345-356. 
volk'. Op de kleine bedrijven op de zandgronden was 'de algemeene regel, dat baas, vrouw en kinderen allen gemeenschappelijk werken op de boerderij; de vrouw doet de keuken, maar ook niet zelden is ze belast met de werkzaamheden in den stal en enkele werkzaamheden op den ${\text { akker. }{ }^{32}}^{32}$

In heel Nederland was het volgens dit rapport 'een algemeen verschijnsel in de zandprovinciën, dat de uitkomsten van de kleine boerderijen, waar men in hoofdzaak werken kan met "eigen volk" [...] buitengewoon veel gunstiger geworden zijn'. ${ }^{33}$ Daarvoor werden verschillende oorzaken aangegeven, waaronder de gestegen lonen van de landarbeiders, waardoor het werken met 'eigen volk' naar verhouding voordeliger werd. Het effect daarvan was in Limburg des te sterker, enerzijds omdat de landarbeiderslonen hier hoog waren door de zuigkracht van de Duitse arbeidsmarkt waar elk jaar duizenden Limburgers naar toe trokken als seizoenarbeiders, anderzijds omdat het aantal kleine bedrijven hier groter was dan vrijwel overal elders in Nederland. ${ }^{34}$ Dit grote aandeel van het kleinbedrijf, dat dreef op meewerkende gezinsleden, verklaart waarom het aantal in de landbouw werkende vrouwen in Limburg sinds het begin van de twintigste eeuw zo hoog was in vergelijking met Nederland als geheel. Nog in $195^{1}$ werd in een vergelijkend onderzoek naar het zogeheten kleine-boerenvraagstuk op de zandgronden in Nederland vastgesteld dat de meeste arbeid werd verricht door de vrouwen in de Limburgse dorpen. ${ }^{35}$

De in het gezinsbedrijf meewerkende boerinnen en boerendochters zijn apart geteld in de beroepstellingen van 1947 en 196o. In tabel 3 zijn die in percentages voor de geselecteerde landbouwdorpen per bedrijfshoofd weergegeven. Eerder bleek dat het aantal vrouwelijke arbeidskrachten in de landbouw volgens de beroepstelling van 1960 in de voorafgaande periode dramatisch zou zijn gedaald, nadat dit tot en met de telling van 1947 redelijk stabiel was gebleven. Uit tabel 3 kan worden afgeleid dat dit een gevolg was van een veel lagere telling van het aantal meewerkende vrouwelijke gezinsleden in 1960. Afgaande op deze telling zouden zij het werk op het boerengezinsbedrijf in het voorafgaande decennium massaal de rug hebben toegekeerd. Het aantal

32 J.J.C. Ament, 'Schets van de ontwikkeling van het landbouwbedrijf op de zandgronden van NoordLimburg, het Land van Weert en het Peelland', in: ibidem 449-464, aldaar 453 en 462-463.

33 Staatscommissie voor den landbouw ingesteld bij K.B. van 20 juni 19o6, No. 72 , Overzicht van het landbouwbedrijf in Nederland ('s-Gravenhage 1912) 307.

34 Ibidem, 227 en 311.

35 A. Maris, C.D. Scheer en M.A. Visser, Het kleine-boerenvraagstuk op de zandgronden. Een economisch-sociografisch onderzoek van het Landbouw-Economisch Instituut (Assen 1951) 147. 
meewerkende boerinnen per mannelijk bedrijfshoofd zou tussen 1947 en 196o zijn gedaald van 45 à 47 naar 4 à 5 procent; dat van boerendochters tot een vergelijkbaar laag percentage. ${ }^{36}$

Tabel 3 Het aantal meewerkende vrouwelijke gezinsleden en externe arbeidskrachten per agrarisch bedrijfshoofd in de geselecteerde landbouwdorpen in Midden-Limburg en het Heuvelland, 1947 en 1960

\begin{tabular}{|c|c|c|c|}
\hline & \multicolumn{2}{|c|}{ Meewerkende gezinsleden (v) } & \multirow{2}{*}{ Arbeidsters** } \\
\hline & Echtgenotes* & Dochters** & \\
\hline \multicolumn{4}{|c|}{ Landbouwdorpen in Midden Limburg } \\
\hline 1947 & $45 \%$ & $47 \%$ & $5 \%$ \\
\hline 1960 & $5 \%$ & $12 \%$ & $2 \%$ \\
\hline \multicolumn{4}{|c|}{ Landbouwdorpen in Heuvelland } \\
\hline 1947 & $47 \%$ & $45 \%$ & $6 \%$ \\
\hline 1960 & $4 \%$ & $7 \%$ & $1 \%$ \\
\hline
\end{tabular}

* per mannelijk bedrijfshoofd

** per mannelijk en vrouwelijk bedrijfshoofd

Voor de selectie van landbouwdorpen: zie noot 23.

Bronnen: zie noot 22.

De conclusie van de landbouwhistorici Jansen en Rutten op basis van deze tellingen dat de vrouwelijke leden van het Limburgse boerengezin 'zich ook op het platteland nu uitsluitend op hun gezinstaak gingen toeleggen' is echter voorbarig. ${ }^{37}$ Er zijn goede redenen om aan te nemen dat de beroepstelling van 196o de omvang van de arbeidsparticipatie van vrouwelijke gezinsleden in de landbouw ernstig onderschat. De belangrijkste reden is dat meewerkende gezinsleden die minder dan 15 uur werkten in de telling van 196o niet met een beroep zijn opgenomen. Hetzelfde geldt voor de telling van 1971. In 1947 was dat wel het geval..$^{8}$

36 In beide teljaren was de bijdrage van extern vrouwelijk personeel verwaarloosbaar klein.

37 J.C.G.M. Jansen en W.J.M.J. Rutten, Geschiedenis van de landbouw in Limburg in de twintigste eeuw (Leeuwarden/Mechelen 1992) 396.

38 A.B. Berends en A.C. Boelmans-Kleinjan, Beroepsarbeid door vrouwen in Nederland [Monografieën Volkstelling 1971, 7] ('s-Gravenhage 1979) 41; zie ook Centraal Bureau voor de Statistiek, $13^{e}$ Algemene Volkstelling 31 mei 196o. Deel 1 o. Beroepsbevolking. A. Algemene inleiding ('s-Gravenhage 1967) 11; Idem, $12{ }^{e}$ Volkstelling annexwoningtelling 31 mei 1947. Serie A. Rijks- en provinciale cïfers. Deel 2. Beroepstelling ('s-Gravenhage 1952) 11. 
Grafiek 6 Het aantal vrouwen werkzaam in de landbouw in Limburg volgens de beroepstellingen $(1947,1960,1971)$ en volgens de landbouwtellingen (1947-1983)

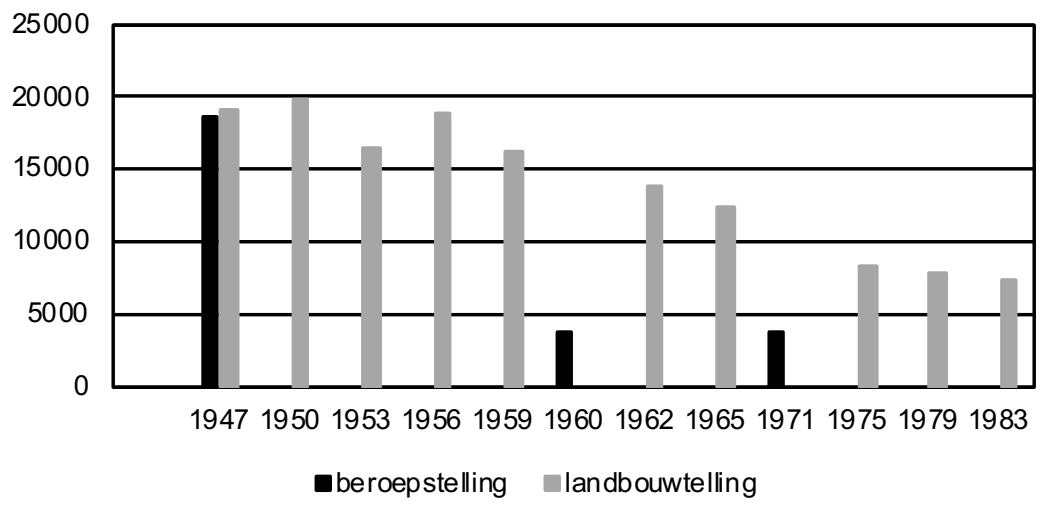

Bronnen: Beroepstellingen 1947, 1960, 1971; CBS, Arbeidskrachten in hoofdzaak voor land- en tuinbouwwerkzaamheden 1947 [Bijzondere statistische opgaven Augustus 1948, no. 8004] (z.p. 1948); CBS, Landbouwtelling 1950 (Utrecht 1952); CBS, Statistiek arbeidskrachten in de land- en tuinbouw December 1956 (Zeist 1958); CBS, Landbouwtelling 1960 Deel 2 (Zeist 1963); CBS, Statistiek arbeidskrachten voor land- en tuinbouwwerkzaamheden 1962 (Zeist 1964); CBS, Statistiek arbeidskrachten voor land- en tuinbouwwerkzaamheden 1965 ('s-Gravenhage 1967); CBS, Landbouwtelling 1975 deel 2: arbeidskrachten voor land-en tuinbouwwerkzaamheden ('s-Gravenhage 1978); CBS, Landbouwtelling 1979 deel 2: arbeidskrachten voor land-en tuinbouwwerkzaamheden ('s-Gravenhage 1981); CBS, Landbouwtelling 1983 deel 2: arbeidskrachten voor land- en tuinbouwwerkzaamheden ('s-Gravenhage 1984).

Het is evenwel mogelijk een beter beeld van het aandeel van vrouwen in het gezinsbedrijf te krijgen door gebruik te maken van de periodieke arbeidskrachtentellingen in de landbouw, die vanaf 1947 om de drie jaar werden gepubliceerd als onderdeel van de landbouwtellingen van het CBS. Zij staan volkomen los van de tienjaarlijkse beroepstellingen en hebben een heel andere grondslag. In tegenstelling tot de beroepstellingen van 196o en 1971 zijn alle op de boerderij meewerkende vrouwen meegeteld, ongeacht de omvang van hun werkzaamheden, dus ook vrouwen die minder dan 15 uur per week aan agrarische arbeid besteedden. Het verschil is zichtbaar in grafiek 6. De uitkomst van de beroepstelling van 1947 komt redelijk overeen met die van de arbeidskrachtentelling van dat jaar, maar in 196o en 1971 is dat geenszins het geval. Gerekend naar het aantal werkzame personen (ongeacht het geschatte aantal arbeidsuren) is de daling van de vrouwelijke arbeidsparticipatie in de landbouw dus veel geleidelijker gegaan dan de vergelijking tussen de beroepstellingen van 1947 en 1960 suggereert. Pas in de jaren 196o begon het aantal in het landbouwbedrijf werkende vrouwen substantieel te dalen. 
Volgens een in 1965 verschenen rapport over de landbouw in Limburg werd er enerzijds door 'de toenemende mechanisatie en rationalisatie [...] tezamen met de veranderende houding ten opzichte van de vrouw $[\ldots]$ vergeleken met vroeger in steeds mindere mate een beroep op de vrouwelijke gezinsleden gedaan', maar was anderzijds 'in alle gebieden een groter aantal vrouwelijke gezinsleden volledig gaan meewerken'. ${ }^{39}$ Deze paradoxale ontwikkeling hing nauw samen met een andere belangrijke verschuiving die zich onder de oppervlakte van de daling van het aantal vrouwelijke arbeidskrachten voordeed, namelijk een sterke afname van de bijdrage van de boerendochters. Dit proces was al in de jaren $195^{\circ}$ aan de gang, getuige een onderzoek uit $195^{8}$ naar de beroepskeuze van boerenjongeren op de zandgronden van Noord-Brabant en Limburg. ${ }^{40}$ Op basis van interviews wordt in verschillende bewoordingen verslag gedaan van de afkeer van boerendochters van het werk op de boerderij. ${ }^{41}$ Als alternatief gingen ze op zoek naar ander werk:

Van de boerenmeisjes hebben velen 'geen lust meer om haar leven lang slavin te zijn'. Daarom zoeken zij werk buitenshuis: de eenvoudigste als werkster; die iets meer kunnen worden gezinsverzorgster, verpleegster, kleuterleidster, onderwijzeres. Dochters van kleine boeren worden ook wel winkelmeisje; naar de fabriek gaat er geen..$^{22}$

Deze boerendochters grepen hun kans om zich te ontplooien in de zich uitbreidende dienstensector. Trouwen met een boer werd daardoor voor hen steeds minder aantrekkelijk. ${ }^{43}$ Een actueel probleem, gezien het populaire Tv-programma 'Boer zoekt vrouw', en ook de oplossing doet verrassend modern aan: 'De boer vindt het heel gewoon dat de vrouw in de stal en zelfs op het land helpt. Hij steekt echter geen hand uit om zijn vrouw eens in de huishouding te helpen, ook al is zij nog zo druk en zou hij er best tijd voor hebben. Dit moet veranderen'.44

39 Commissie voor de Agrarische Belangen in Limburg, Agrarische welvaartsstudie 1965 (Maastricht [1965]) 77 en 85 .

40 N.H.H. Addens, Over de beroepskeuze van boeren jongeren op de zandgronden van Noord-Brabant en Limburg ('s-Gravenhage 1959).

41 Ibidem, 7 o.

42 Ibidem, 73.

43 Ibidem, 74.

44 Ibidem, 75 
Grafiek 7 Het percentage vrouwelijke bedrijfshoofden en meewerkende echtgenotes in het totaal van de vrouwelijke gezinsarbeidskrachten in de landbouw in Limburg, 1947-1983

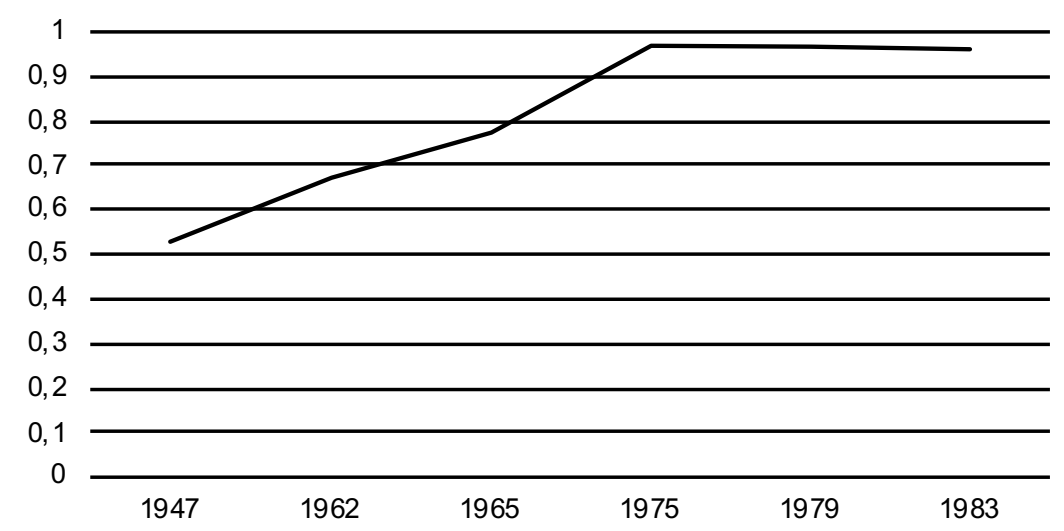

Bronnen: SHCL: Collectie CBS-statistieken, BH 1: Uitkomsten van de Volks-en Beroepstelling, 31 Mei 1947. Prov. Limburg; Landbouwtellingen 1962-1983 (zie grafiek 6).

Uit een uitsplitsing van de cijfers over de vrouwelijke gezinsarbeidskrachten naar de positie in het gezin op basis van de beroepstelling 1947 en de landbouwtellingen vanaf 1962 blijkt dat het aandeel van echtgenotes en vrouwelijke bedrijfshoofden in de gezinsarbeid op de boerderij in de jaren 1950 en 1960 inderdaad sterk toenam van 53 procent in 1947 naar ca. 97 procent in de jaren 1970 en 1980 (grafiek 7).

De verdwijning van de boerendochters als arbeidskracht op de boerderij in deze periode kan zeker ook als onderdeel van de 'stille revolutie' in de vrouwelijke arbeidsparticipatie in Limburg worden beschouwd, met grote maatschappelijk consequenties. Zo heeft de historicus Paul Klep de afvloeiing van de meewerkende kinderen op de kleine boerenbedrijven in verband gebracht met de daling van de huwelijksvruchtbaarheid in de katholieke zuidelijke provincies in de jaren $195^{\circ}$ en 1960. ${ }^{45}$ Kinderen waren daardoor immers minder 'nuttig' voor de bedrijfsvoering. Onder verwijzing naar een onderzoek van de Katholieke Nederlandse Boeren- en Tuinders Bond over de 'relaties en de sfeer in het agrarische gezin' stelt hij vast dat het gezag van het boerengezinshoofd - de vader - door het uitvliegen van de kinderen afbrokkelde. Doordat vele kinderen, waaronder dus de dochters, hun toekomst buiten het gezinsbedrijf zochten, was de traditionele positie van de vader

45 Zie onder meer P. Klep, 'Kleine boeren en grote gezinnen in crisistijd (1920-1970). Een nieuwe these', in: J. Kok en J. Van Bavel (red.), De levenskracht der bevolking. Sociale en demografische kwesties in de Lage Landen tijdens het Interbellum (Leuven 2010) 141-196. 
als bedrijfshoofd, werkgever en leermeester aanzienlijk verzwakt. Anders gezegd: het patriarchale karakter van de ouder-kindrelaties werd aangetast. ${ }^{46}$

In de jaren 1950 en 196o werd het boerengezinsbedrijf en de positie van de vrouw daarin ook onderwerp van sociologisch onderzoek in $\mathrm{Ne}-$ derland, met name op de (toen nog) Landbouwhogeschool in Wageningen. ${ }^{47}$ Het boerengezin zou zich in een proces van modernisering bevinden, hetgeen onder meer tot uiting kwam in een toenemende scheiding tussen wat genoemd werd 'productieve' landbouwwerkzaamheden en 'consumptieve' gezinstaken. De boerin zou steeds meer uit het bedrijf verdwijnen om zich te concentreren op haar huishoudelijke werkzaamheden, ofwel haar 'essentiële gezinsfuncties', met als gevolg een 'niveauwinst van het gezin'. ${ }^{48}$ Deze 'functiereductie der vrouwelijke bedrijfstaak' zou volgens deze sociologen leiden tot de 'feminisering van de boerenvrouw', niet in de zin van 'emancipatie', maar van 'een vrouwelijker-worden, meer nog: een nieuw existentiële beleving van haar vrouw zijn, met als symptomen een toenemende aandacht voor haar uiterlijk, voor lichaamsverzorging, kleding en haardracht'. 49 Impliciet werd hiermee de bedrijfsarbeid door de boerin dus als 'onvrouwelijk' getypeerd.

De sociologische moderniseringsthese over het boerengezin werd in de jaren 1950 en 1960 omgezet in beleid in de zogeheten 'huishoudelijke voorlichting ten plattelande', die vooral gericht was op de rol van de boerin als huisvrouw en gezinsverzorgster. Ook in Limburg was dit het geval..$^{50}$ De relatieve stijging van het aandeel van meewerkende echtgenotes in het boerenbedrijf geeft aan dat de boerinnen zich er weinig van hebben aangetrokken.

46 Ibidem, 151; Idem, 'De Nederlandse katholieke boerenbonden en de agrarische gezinsproblematiek 1930-1962', Trajecta. Tijdschrift voor de Geschiedenis van het Katholiek Leven in de Nederland [Moeizame moderniteit. Katholieke cultuur in transitie. Opstellen voor Jan Roes (1939-2003)] 13 (2004) 316-341, aldaar 328-333; кNBTB, De relaties en de sfeer in het agrarisch gezin ('s-Gravenhage 1961).

47 Vgl. E.H. Karel, 'Boer en gezin. De sociologisering van het boerenbestaan', in: Idem, Boeren tussen markt en maatschappij. Essays over effecten van de modernisering van het boerenbestaan in Nederland (1945-2012) (Groningen/Wageningen 2013) 103-129.

48 Saal, Het boerengezin, 234.

49 Ibidem, 204-205 en 233.

5o Vgl. E.H. Karel, 'Streekverbetering in Nederland en in Limburg, 1956-1970', Studies over de sociaaleconomische geschiedenis van Limburg/Jaarboek van het Sociaal Historisch Centrum voor Limburg LI (2006) 55-8o, aldaar 74 . 


\section{Vrouwenarbeid in de Maastrichtse glas- en aardewerkin- dustrie}

De glas- en aardewerkfabrieken verschaften veel werk aan Maastrichtse vrouwen. Van de in 1909 getelde vrouwen met een beroep namen die 83 procent van de fabrieksarbeid door vrouwen voor hun rekening. Daarnaast waren er vrouwen in de papier-, spijker- en tabaksfabrieken, maar in aanzienlijk lagere aantallen. ${ }^{{ }^{1}}$ Omdat er ook veel vrouwen uit de omliggende dorpen in de Maastrichtse industrie werkten, was het aantal vrouwen in de fabrieken nog flink wat hoger dan de beroepstelling aangeeft..$^{5^{2}}$ Die telde immers alleen de in Maastricht woonachtige beroepsbevolking. Volgens het in hetzelfde jaar gehouden onderzoek naar de fabrieksarbeid van gehuwde vrouwen in Nederland werkten er 1.819 vrouwen in de Maastrichtse glas- en aardewerkfabrieken, dat is 334 meer dan volgens de beroepstelling, die dus volgens deze redenering in de omliggende gemeenten zouden hebben gewoond. ${ }^{53}$

Gezien het overwicht van de glas- en aardewerkindustrie in de werkgelegenheid voor vrouwen richt het vervolg zich op deze bedrijfstak, en dan vooral op het bedrijf de Sphinx. Er waren meer aardewerkfabrieken in Maastricht, onder meer de Société Céramique en de Mosa, maar de Sphinx was de oudste en de grootste. Bovendien is het archief goed overgeleverd en ontsloten. De Sphinxfabrieken waren in 1834 opgericht door de 'stamvader' van de fabrikantenfamilie Regout, Petrus I. Vanaf 1899 stond dit bedrijf bekend onder de naam 'de Sphinx'. Vooral na het midden van de negentiende eeuw nam het aantal arbeiders in zijn fabrieken sterk toe. Het grootste aantal werd in 1914 bereikt met ruim 3.700 werknemers. ${ }^{54}$

51 Over de arbeid van vrouwen bij de Koninklijke Nederlandsche Papierfabriek (KNP) in Maastricht: G. de Groot, Fabricage van verschillen. Mannenwerk, vrouwenwerk in de Nederlandse industrie (1850-1940) (Amsterdam 2001) hoofdstuk 8: 'Conducteurs en sorteerster. De Koninklijke Nederlandse Papierfabriek'; over de Maastrichtse spijkerfabriek: E. van Royen, 15 o jaar Thomas Regout N.V. Geschiedenis van een Maastrichts metaalverwerkend bedrïf, 1 834-1984 (Maastricht 1984).

$5^{2}$ Zie hierover ook C. Cillekens, 'Aardewerk en arbeidsmarkt. Maastricht tussen de twee wereldoorlogen', Studies over de sociaaleconomische geschiedenis van Limburg/Jaarboek van het Sociaal Historisch Centrum voor Limburg LII (2007) 115-135, aldaar 11 7-118.

53 Directie van den Arbeid, Onderzoek naar den fabrieksarbeid van gehuwde vrouwen in Nederland ('s-Gravenhage 1911) 53. Het door Van Eijl, Het werkzame verschil, 45, noot 24 geconstateerde verschil in het aantal gehuwde vrouwen in de glas- en aardewerkfabrieken in Maastricht volgens dit onderzoek en de beroepstelling kan hiermee ook worden verklaard.

54 Van Vugt, Een arbeidersbuurt onder de rookvan 'De Sphinx', 173. 


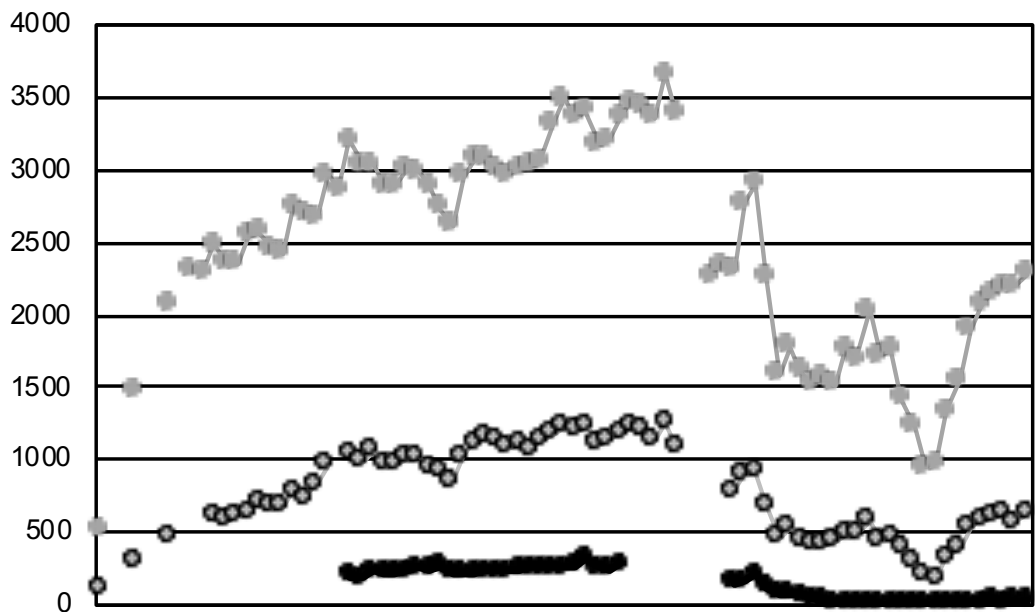

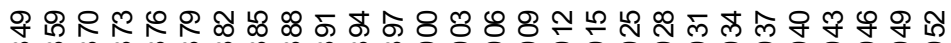

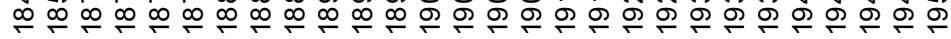

$\longrightarrow$ vrouwen gehuwd $\_$vrouwen gehuwd en onge huwd $\_$totaal vrouwen en mannen

Bronnen: SHCL, archief Sphinx, EAN 1012, inv. nr. 126, Contractenboeken 1848-1850, pp. 72-75: 'Staat van het personeel in de diverse Fabrijken van den Wel Edelen Heer P. Regout te Maastricht opgemaakt in Julij 1849'; inv. nr. 129, Contractenboeken 1857-1859, p. 132f.: 'Staat der werklieden welke op den 1 Januarij 1859 in de fabriek werkzaam zijn volgens eene nominatieve lijst'; inv. nr. 133, Contractenboeken 1867-1870, pp. 396-397: 'Staat aanwijzende het aantal Heeren Employés en werklieden gebezigd in de fabrijken van den Heer P. Regout op 1 Januarij 1870'; inv. nr. 723, Jaarverslagen van de Sociale Afdeling, 1926-1955; inv. nr. 823. Bevolkingsregister 1 Mei 1874-1 Mei 1885: 'Staat van opneming van het personeel in dit Register vermeld'; inv. nr. 830, 'Vergelijkende staten van aantallen mannelijke en vrouwelijke werknemers ...'; inv. nr. 1768, 'Vergelijkende staten van verkoop, fabricatie enz.'; SHCL, archief Sphinx (aanvulling), EAN 1015, 'Naamlijst van het Personeel van de Kristal-, Glas- en Aardewerkfabrieken "de Sphinx" voorheen Petrus Regout \& Co te Maastricht', 1900-1912: 'Staat van opneming van het personeel.'

Grafiek 8 laat zien dat dit aantal in de rest van de twintigste eeuw niet meer werd gehaald. Gegevens over de periode van de Eerste Wereldoorlog en de eerste helft van de jaren 1920 ontbreken, maar er is voldoende informatie om in die jaren van een ernstige crisis in de glas- en aardewerkindustrie te spreken, met een grote werkloosheid onder de glas- en aardewerkers en -werksters als gevolg. in 1925 leidde de crisis tot het afstoten van de glasfabriek door Sphinx. Na een korte opleving in de late jaren 1920, stortte de werkgelegenheid in de jaren 1930 compleet in..$^{55}$ 
Grafiek 9 Het aandeel van vrouwen in de totale fabrieksbevolking en het aandeel van gehuwde vrouwen in het totale aantal werkzame vrouwen bij Sphinx (vóór 1899 Petrus Regout \& Co) (percentages), (1849) 1874-1915 en 1925-1953.

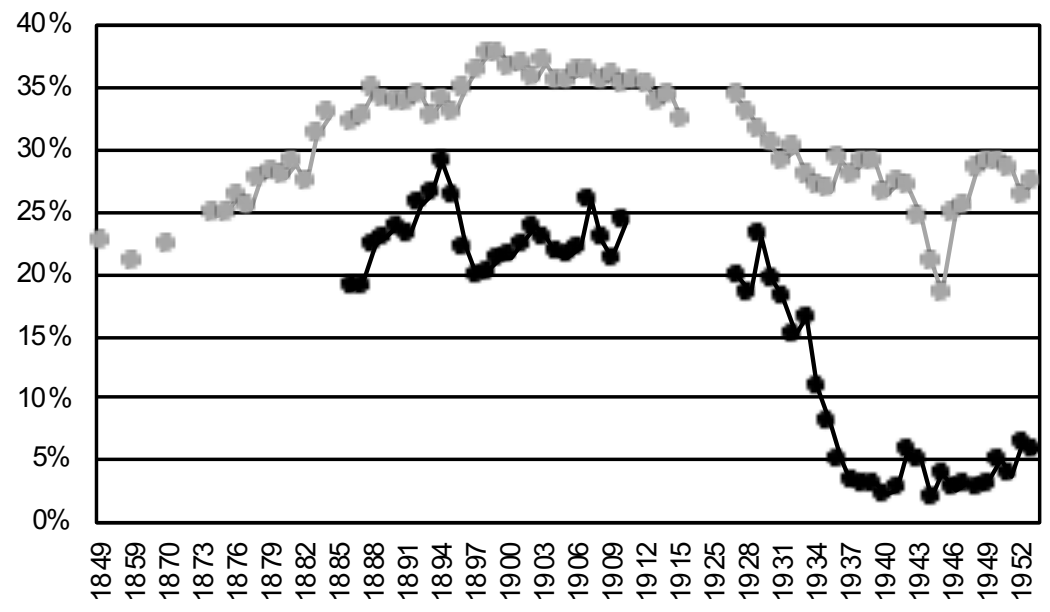

—_ $\%$ vrouwen $\%$ vrouwen gehuwd

Bronnen: zie grafiek 8.

Om de groei van de fabrieken van Regout in de tweede helft van negentiende eeuw mogelijk te maken rekruteerde hij naar verhouding meer vrouwen dan mannen. Het percentage in zijn fabriek werkzame vrouwen groeide van 20 tot 25 procent in de jaren 1850 en 186 o naar 35 tot maximaal 38 procent in de jaren 188 o en 1890 (zie grafiek 9 ). In het begin van de twintigste eeuw bleef dit percentage ongeveer even hoog, en ook aan het eind van de jaren 1920 was het nog altijd 34 procent. Daarna zette een daling in. Afgezien van een abnormaal dieptepunt in de oorlogsjaren, varieerde het aandeel van vrouwen in de jaren 1930 en 1940 tussen de 26 en 29 procent. De daling van het aantal vrouwen vanaf 1930 deed zich ook voor in de beroepsbevolking in de Maastrichtse glas- en aardewerkindustrie als geheel en is dus niet specifiek voor het bedrijf 'de Sphinx' ${ }^{56}$

De relatieve groei van het aantal vrouwen in de Regout-fabrieken in de tweede helft van de negentiende eeuw was een gevolg van de sterke uitbreiding van de aardewerksector in zijn bedrijf. In zijn dissertatie over de seksesegregatie in de Nederlandse industrie in deze periode heeft Gertjan de Groot laten zien dat er bij Sphinx een vaste verdeling was in het werk tussen mannen en vrouwen. Die had Regout overge- 
nomen van de Engelse bedrijven waarvan hij het productieproces had geïmiteerd met behulp van speciaal geworven vakmensen. ${ }^{57}$ Vrouwen werkten voor het overgrote deel als ovenwerksters bij het vullen en leeghalen van de cassetten met te bakken en gebakken aardewerk en het aanreiken daarvan aan de mannelijke ovenwerkers; bij het schilderen, decoreren, bedrukken en vernissen van aardewerk; en bij het sorteren, inpakken en verzenden van de eindproducten in het magazijn. Naarmate de productie van aardewerk belangrijker werd ten opzichte van glas en kristal, moesten er voor deze taken relatief meer vrouwen worden geworven.

Tabel 4 Het aantal mannen en vrouwen in de aardewerk- en sanitairafdelingen bij Sphinx, 1932 en 1948

\begin{tabular}{|l|r|r|r|r|r|r|r|r|}
\hline & \multicolumn{2}{|c|}{ Mannen } & \multicolumn{2}{c|}{ Vrouwen } & \multicolumn{2}{c|}{ Totaal } & \multicolumn{2}{c|}{$\%$ Vrouwen } \\
\hline & 1932 & 1948 & 1932 & 1948 & 1932 & 1948 & 1932 & 1948 \\
\hline Aardewerk & 370 & 298 & 248 & 368 & 618 & 666 & $40 \%$ & $55 \%$ \\
\hline Sanitair & 271 & 421 & 104 & 3 & 375 & 424 & $28 \%$ & $7 \%$ \\
\hline $\begin{array}{l}\text { Algemene dienst/ } \\
\text { Niet in te delen }\end{array}$ & 167 & 372 & 7 & 25 & 174 & 397 & $4 \%$ & $6 \%$ \\
\hline Totaal & $\mathbf{8 0 8}$ & 1.091 & 359 & 396 & 1.167 & 1.487 & $31 \%$ & $27 \%$ \\
\hline
\end{tabular}

Bronnen: IISG, archief Nederlandse Vereniging van Fabrieksarbeiders(sters), arch.nr. 00993, inv. nr. 47: De Sphinx, Societe Ceramique, NV Kristal Unie 1932: 'Personeel per 22 Januari '32.' Zie ook De Groot, Fabricage van verschillen, 269 (mijn berekening wijkt op onderdelen af); SHCL, archief Sphinx, EAN 1012, inv. nr. 829: Personeelslijst 1947-1950.

Andersom heeft de daling van het aandeel van vrouwen in het Interbellum en daarna te maken met de relatieve afname van de aardewerkproductie ten opzichte van de productie van sanitair, zoals toiletten en wastafels. Dat werd steeds meer het hoofdproduct van Sphinx, tot de aardewerkafdeling in 1969 werd gesloten. Aanvankelijk werden vrouwen ook bij taken in de sanitairproductie ingeschakeld, maar uit een overzicht uit 1948 blijkt dat er na de Tweede Wereldoorlog nauwelijks nog vrouwen in de sanitairafdelingen werkten (zie tabel 4). Door de introductie van transportbanden en vernismachines werden voorheen door vrouwen uitgevoerde werkzaamheden overbodig. Bij de sluiting van de aardewerkfabriek in 1969 konden de mannen in de sanitairfabriek worden herplaatst; voor de 200 vrouwelijke werkneemsters was dat niet mogelijk..$^{8}$ 


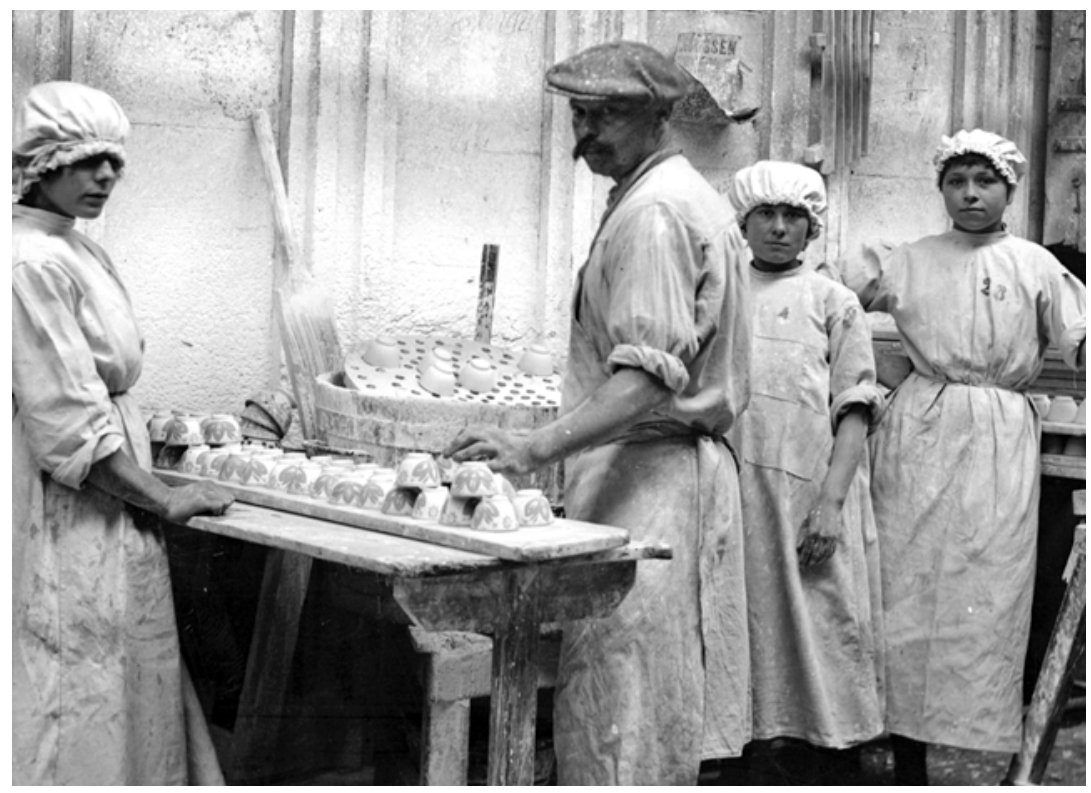

Illustratie 4 Een werkploeg op de vernisafdeling van de Sphinx aardewerkfabriek, ca. 1930. Op deze foto wordt de dompelmethode gehanteerd, waarbij de man het ruwe aardewerk met de hand in een glazuurbad dompelt. Hij wordt geassisteerd door vrouwelijke hulpen (bron: SHCL, fotocollectie Sphinx-Céramique).

Uit het onderzoek naar de fabrieksarbeid van gehuwde vrouwen in Nederland uit 1909 blijkt dat die in Maastricht tot de hoogste van het land behoorde, zowel in absolute als in relatieve zin. ${ }^{59}$ Volgens het onderzoeksrapport maakte de 'groote uitgebreidheid van den vrouwenarbeid, die de geheele bevolking aldaar gewent aan het fabrieksleven, het begrijpelijk dat meerdere vrouwen na haar huwelijk den arbeid blijven voortzetten. ${ }^{60}$ Elders in het rapport wordt een verband met de kinderarbeid geconstateerd: 'Evenals bij de glasfabrikage zijn de gehuwde arbeidsters [in de aardewerkfabrieken] voor het groote meerendeel van kind af aan den fabrieksarbeid gewoon. Er waren er 18 die reeds vóór het twaalfde jaar, één zelfs, die op haar $8^{\text {ste }}$ jaar daarmede begonnen waren', ${ }^{61}$

Dat de gehuwde vrouwen in de aardewerkindustrie hun eerder begonnen arbeid voortzetten, zoals door deze onderzoekers werd vastgesteld, was staand beleid in de fabrieken van de Regouts. Dat blijkt uit een antwoord van Louis Regout in de arbeidsenquête van 1887:

59 Directie van den Arbeid, Onderzoeknaar den fabrieksarbeid, 28-29: Staat IIIc.

6o Ibidem, 53 .

61 Ibidem, 54. 
Getrouwde vrouwen worden bij ons in den regel niet aangesteld. Doch wanneer zij als meisje bij ons werkzaam zijn en zij trouwen, dan vinden wij geen reden om ze te bedanken; vandaar dat wij betrekkelijk zoveel getrouwde vrouwen op de fabriek hebben. Die vrouwen blijven hetzelfde werk verrichten dat zij als meisje deden $[\ldots]^{62}$

Vanaf 1893 verbood de directie officieel om gehuwde vrouwen aan te nemen die voor hun huwelijk niet in de aardewerkfabriek hadden gewerkt, maar dit verbod werd soepel toegepast. ${ }^{63}$ De ervaring die de vrouwen vóór hun huwelijk hadden opgedaan maakte hun arbeidsinzet daarna des te waardevoller. Vandaar dat de directie vooral belang hechtte aan het doorwerken van eerder aangenomen en inmiddels ingewerkte vrouwen. Om dat mogelijk te maken was het vrouwen toegestaan pasgeboren kinderen mee te nemen naar de fabriek om ze daar te verzorgen. Zo memoreerde het SDAP-raadslid Anna Wynandts-Louis in de jaren 1920 dat 'haar moeder van 's morgens half zeven in de drukke tijden tot 's nachts 12 uur in de fabriek moest werken, terwijl haar kind in een z.g. mand, in werkelijkheid was het een kist, naast haar lag en de algehele verzorging van het kind in de fabriek moest plaats hebben' ${ }^{64}$ Maar daar was wel een grens aan, die vrij precies was bepaald op het krijgen van een derde kind. Voor de enquêtecommissie stelde Louis Regout het zo voor dat dit een soort gewoonte was:

Dat te huis blijven der vrouw heeft een gewonen gang, die vrij regelmatig is. Als zij twee kinderen hebben, beginnen zij zachtjes aan verlof te vragen om te huis te blijven; dan hebben zij een kind ziek, dan is er iets anders; en als zich dat wat herhaalt, zegt de opzichter vanzelf: Nu wordt het tijd, dat gij te huis blijft. ${ }^{65}$

In 1895 werd ook officieel door de bedrijfsleiding verordonneerd dat vrouwen na de derde bevalling niet meer aangenomen mochten worden. Ook dit gebod werd soepel toegepast al naar gelang de behoefte

62 J. Giele (red.), Een kwaad leven. De arbeidsenquête van 1887. Heruitgave van de Enquête betreffende werking en uitbreiding der wet van 19 september 1874 (Staatsblad no. 130) en naar den toestand van fabrieken en werkplaatsen (Sneek 1887) deel 2: Maastricht, 120, verhoor Louis Regout, antw. 6617, geciteerd in De Groot, Fabricage van verschillen, 279.

63 Ibidem, 281.

64 Geciteerd door J.J.G. Luijten, 'Anna-Cornelia Wynandts-Louis, eerste vrouwelijk raadslid van Maastricht en Nederland. Een glasslijpersfamilie in de greep van Regout', in: I.M.H. Evers e.a. (red.), Bonne et servante. Uit de geschiedenis van de Maastrichtse vrouw (Maastricht 1986) 101-109, aldaar 101. 65 Geciteerd in De Groot, Fabricage van verschillen, 28o. 
van het bedrijf aan arbeid door deze vrouwen.$^{66}$ Niettemin kon Thijs van Vugt op basis van de personeelsadministratie van Sphinx vaststellen dat het werk van gehuwde vrouwen in de fabrieken afnam naarmate het huwelijk vorderde en er meer kinderen werden geboren. ${ }^{67}$

Het aandeel van de gehuwde vrouwen in het vrouwelijke personeelsbestand bij Sphinx was omstreeks 1895 op zijn hoogst: tussen de 26 en 29 procent (zie hiervóór, grafiek 9). In de jaren daarna werd dit met 20 tot 25 procent iets lager. Deze verhouding gold ook nog aan het eind van de jaren 1920 (23 procent in 1929), maar daarna nam het aandeel pijlsnel af tot slechts 3 procent in 1937 en de daarop volgende jaren. De verklaring kan eenduidig worden gevonden in het personeelsbeleid van de directie van Sphinx: vooruitlopend op de invoering van betaald zwangerschapsverlof in de Ziektewet van 1930 besloot men met ingang van 193 o dat er geen gehuwde vrouwen meer werden aangesteld en dat 'elke werkneemster welke niet 5 jaren in dienst was, bij huwelijk ontslagen zou worden' ${ }^{68}$ De Ziektewet bepaalde dat het loon van gehuwde vrouwen zes weken voor en zes weken na de bevalling moest worden doorbetaald. Blijkbaar vond de directie van Sphinx dat te duur, maar er werd ook door de vakbonden geen bezwaar gemaakt. In de zowel door de katholieke als de socialistische fabrieksarbeidersbonden ondertekende CAO met Sphinx uit 1934 werd bepaald dat het sluiten van een huwelijk door een arbeidster een dringende reden tot onmiddellijk ontslag was. ${ }^{69}$

Omdat de directie had bepaald dat vrouwen met meer dan een vijfjarig dienstverband bij huwelijk niet hoefden te vertrekken, verliep de daling van het aantal gehuwde vrouwen in de fabriek geleidelijk. In 1933 waren er om die reden nog 23 vrouwen bij hun huwelijk in dienst gebleven, maar daarna daalde dit aantal van jaar op jaar tot dit in 1940 niet meer voorkwam. ${ }^{70}$ Om vervanging te vinden voor de gehuwde vrouwen moest Sphinx op zoek naar meer jonge ongehuwde vrouwen en meisjes. Omdat die bij huwelijk weer werden ontslagen nam ook de roulatie toe en werd de vraag nog groter. Sphinx vond dit nadeel blijk-

66 Ibidem, 280-282.

67 Van Vugt, Een arbeidersbuurt, 154. Deze afname van loonarbeid door gehuwde vrouwen na een aantal jaren huwelijk was overigens een normaal verschijnsel in deze tijd: A. Knotter, 'Gezinsarmoede-gezinsarbeid. De invloed van de gezinscyclus op de gezinnen van losse (haven)arbeiders in Amsterdam in de eerste helft van de twintigste eeuw', Tijdschrift voor Sociale Geschiedenis 24 (1988) 371-401.

68 SHCL, archief Sphinx, EAN 1012, inv. nr. 723, Jaarverslag van de Sociale Afdeling, 193 o.

69 IISG, archief Nederlandse Vereniging van Fabrieksarbeiders(sters), arch.nr. oo993, inv. nr. 51: De Sphinx, Societe Ceramique, Nv Kristal Unie: 'Collectieve arbeidsovereenkomst voor de N.V. Kristal-, Glas- en Aardewerkfabrieken “De Sphinx”, voorheen Petrus Regout \& Co. Te Maastricht'.

70 SHCL, archief Sphinx, EAN 1012, inv. nr. 723, Jaarverslag van de Sociale Afdeling, 1932-1940. 
baar minder groot dan het verlies aan ervaring van de gehuwden. De kostenfactor was hier doorslaggevend..$^{71}$

Het was echter niet zo gemakkelijk om voldoende meisjes en ongehuwde jonge vrouwen aan te trekken. In 1932 werd door de directie vastgesteld: 'Uit Maastricht zelf melden zich vrijwel geen vrouwen', en in 1934: 'Voor wat speciaal vrouwelijke werkkrachten betreft, hebben wij steeds kunnen constateeren dat het aanbod uit Maastricht niet voldoende was [...]'. Men trok daarom vrouwelijk personeel aan uit Belgische grensdorpen, met name uit Lanaken en omgeving, en ook 'meisjes van vreemde nationaliteit (Polen, Hongaren, Czechen en dergelijke) uit de Belgische mijnstreek. $7^{2}$ Vanaf juli 1939 werd er intensief geworven in de Nederlandse mijnstreek, met als resultaat dat er in dit en volgende jaren elkjaar tussen de 100 en 150 zogenoemde 'mijnstreek-meisjes' konden worden aangesteld. De personeelsafdeling van Sphinx ging ervan uit dat Belgische en 'mijnstreek-meisjes' blijvend 30 à 35 procent van de vrouwelijke arbeidsbezetting zouden vormen. ${ }^{73}$ In de jaren $195^{\circ}$ liepen de aanmeldingen uit de mijnstreek echter sterk terug, omdat daar steeds meer werkgelegenheid kwam voor meisjes tegen een vergelijkbaar loon, bijvoorbeeld bij de recent gevestigde Philipsfabriek of bij de tricotageateliers. ${ }^{74}$

De uitstoting van gehuwde vrouwen uit het arbeidsproces door Sphinx in de jaren 1930 was niet direct bedoeld om de effectiviteit van de wederzijdse arbeidsinzet van de huwelijkspartners in het mannelijke kostwinnersgezin te vergroten, maar viel wel samen met een reorganisatie en vernieuwing van de bedrijfsvoering die men 'Fordistisch' zou kunnen noemen. Met de overgang naar sanitair als hoofdproduct, de rationalisering van de productie door de concentratie daarvan in het nieuwgebouwde Eiffelgebouw, de ingebruikneming van de veel efficiëntere tunnelovens, de verwetenschappelijking van de techniek, de wijzigingen in de arbeidsorganisatie die daarmee gepaard ging, en last but not least de normalisering van de arbeidsverhoudingen door nu eindelijk een collectieve arbeidsovereenkomst te sluiten, nam de bedrijfsleiding van Sphinx in deze jaren op tal van terreinen afscheid van de negentiende-eeuwse manier van werken. ${ }^{75}$ Het terugdringen van de arbeid door vrouwen - gehuwd en ongehuwd - past hierin.

\footnotetext{
71 Vgl. De Groot, Fabricage van verschillen, 239-240, 246-247.

72 Geciteerd door ibidem, 283-284.

73 SHCL, archief Sphinx, EAN 1012, inv. nr. 723, Jaarverslag van de Sociale Afdeling, 1939-1944.

74 Ibidem, 1954.

75 Deze gelijktijdig optredende veranderingsprocessen worden beschreven in verschillende bijdragen in A. Knotter (red.), Keramiekstad. Maastricht en de aardewerkindustrie in de negentiende en twintigste eeuw (Zwolle/Maastricht 2016).
} 
De 'stille revolutie' in de vrouwelijke arbeidsparticipatie in Limburg is in de Maastrichtse aardewerkfabrieken niet alleen zichtbaar in de daling van het aandeel van vrouwen en de verwijdering van gehuwde vrouwen uit het arbeidsproces, maar ook in de manier waarop daarna jonge vrouwen werden ingezet, namelijk alleen als tijdelijke en roulerende arbeidskrachten. Het hoogtepunt van de vrouwelijke arbeidsinzet in Maastricht viel samen met de bloeitijd van de aardewerkindustrie tussen circa 1880 en 1915. In de jaren daarna verloor de vrouwenarbeid in de fabrieken als vaste waarde steeds meer terrein. De aard van die arbeid veranderde: aanvankelijk kon de entree van vrouwen in de fabrieken op jonge leeftijd een opstap zijn naar een meer ervaren beroepsuitoefening op latere leeftijd, al of niet in gehuwde staat, maar in de jaren 1930 werd dit opgegeven voor een roulerende tewerkstelling van meisjes aan wie geen verder loopbaanperspectief in het vooruitzicht werd gesteld. Dat deze meisjes voor een aanzienlijk deel uit de mijnstreek moesten worden gerekruteerd is niet toevallig. Door de eenzijdige samenstelling van de werkgelegenheid in de mijnindustrie, die alleen aan mannen werk bood, bestond er daar een groot tekort aan arbeidsplaatsen voor meisjes en jonge vrouwen, vooral mijnwerkersdochters, maar alleen zolang zij niet als gehuwde vrouwen hun noodzakelijke reproductieve rol in de mijnwerkersgezinnen konden opnemen. De roulerende arbeidsvraag bij Sphinx in Maastricht vond daarom zijn pendant in de eenzijdig voor arbeid door mijnwerkersdochters ingerichte confectie- en tricotageateliers in de beide mijnstreken. Op deze manier werd het mannelijke kostwinnersgezin zowel in de mijnstreken als in Maastricht in stand gehouden dan wel versterkt.

\section{Conclusie: een stille revolutie}

In Limburg als geheel bestond er tot en met de beroepstelling van 1909 een - zij het beperkte - oververtegenwoordiging van vrouwen in de industrie. Die kan grotendeels worden toegeschreven aan de sterke aanwezigheid van vrouwen in de Maastrichtse glas- en aardewerkfabrieken. De ondervertegenwoordiging van vrouwen in de industrie in de beroepstellingen daarna is echter niet alleen een gevolg van de daling van het aandeel van vrouwen in deze bedrijfstak, maar vooral van de groei van de werkgelegenheid in mijnbouwsector, waarin het mannelijke kostwinnersgezin overheerste. In de mijnstreken was de vrouwelijke arbeidsparticipatie veel lager dan in andere gebieden van Limburg, met 
name daar waar het boerengezinsbedrijf overheerste. De 'stille revolutie' in de vrouwelijke arbeidsparticipatie in Limburg is daarom allereerst een statistisch gevolg van de snelle opkomst van de mijnindustrie in de periode tussen de beroepstellingen van 1909 en 1930 en de relatieve afname van de landbouw als middel van bestaan.

Het is tekenend voor de veerkracht - of zo men wil inertie - van het boerengezinsbedrijf met zijn grote inzet van vrouwelijke arbeidskracht dat dit tot na de Tweede Wereldoorlog bleef zorgen voor een Limburgse voorsprong in de vrouwelijke arbeidsparticipatie, zij het in afnemende mate (zie hiervóór grafiek 1). De omslag in de jaren 1950 was weliswaar minder abrupt dan de beroepstelling van 1960 suggereert, maar in de jaren 1950 en 1960 nam het aantal vrouwelijke arbeidskrachten in de landbouw wel af. Deze afname ging gepaard met een verschuiving die tegengesteld was aan die in de Maastrichtse industrie en de mijnwerkersgezinnen: de rol van de boerin als meewerkende echtgenote werd sterker, die van de in het gezinsbedrijf werkende boerendochters verdween. Ook hier vond dus een dubbele evolutie plaats: de afname van de vrouwenarbeid ging gepaard met een verschuiving wat betreft de huwelijkse staat en de leeftijdsopbouw van de werkende vrouwen in de landbouw, maar dan in omgekeerde zin.

Deze bevindingen in Limburg ondersteunen de conclusie in het recente proefschrift van Corinne Boter, dat een verklaring voor de opkomst van het mannelijke kostwinnersgezin niet alleen aan de aanbodzijde (het hoge mannelijke loonpeil), maar ook aan de vraagzijde van de arbeidsmarkt voor vrouwen moet worden gezocht. Er waren grote verschillen in de ontwikkeling per bedrijfstak en sector, met als tegenpolen de mijnbouw, die bij uitstek steunde op het mannelijke kostwinnersmodel met als gevolg een lage vrouwelijke arbeidsparticipatie, en de landbouw, die werd beheerst door boerengezinsbedrijven met een grote inzet van vrouwelijke arbeidskracht. De Maastrichtse industrie kende dan weer een eigen ontwikkeling.

De in dit artikel onderzocht bedrijfstakken representeren elk één van de drie typen in de klassieke categorisering van Tilly en Scott: de gezinsarbeid in de landbouw is een voorbeeld van de family economy, de loonarbeid van vrouwelijke gezinsleden in de Maastrichtse industrie van de family wage economy, en het strikte kostwinnersmodel in de gezinnen van mijnwerkers van de family consumer economy. Het feit dat deze drie economische gezinstypen in Limburg gedurende een groot deel van de twintigste eeuw tegelijkertijd voorkwamen, geeft aan dat deze classificatie niet zonder meer in een lineaire opeenvolging moet 
worden gezien, zoals Tilly en Scott impliceerden. Ook de ontwikkeling van de economische gezinsstructuur in deze bedrijfstakken, waar het in de discussie over de opkomst van het mannelijke kostwinnersgezin in feite om gaat, kan niet eenduidig worden geplaatst in een evolutie van family economy via family wage economy naar family consumer economy. Door de inzet van echtgenotes in het boerengezinsbedrijf bleef dat trekken van de family economy behouden, maar voor zover de boerenzoons en -dochters hun elders verdiende loon aan hun ouders moesten afstaan, zoals nog tot ver in de jaren 196o gebruikelijk was, is hier ook sprake van een family wage economy. Dat laatste geldt natuurlijk ook voor de inkomsten van zoons en dochters in mijnwerkersgezinnen, hoewel die gezien de eenzijdige huishoudelijke arbeid van de mijnwerkersvrouw als family consumer economy zouden kunnen worden beschouwd.

\section{Over de auteur}

Ad Knotter (1952) was tot 2018 directeur van het Sociaal Historisch Centrum voor Limburg en hoogleraar in de vergelijkende regionale geschiedenis, in het bijzonder die van Limburg aan de Universiteit Maastricht. Thans is hij honorary professor bij die universiteit en research fellow bij het Internationaal Instituut voor Sociale Geschiedenis.

E-mail: a.knotter@maastrichtuniversity.nl 


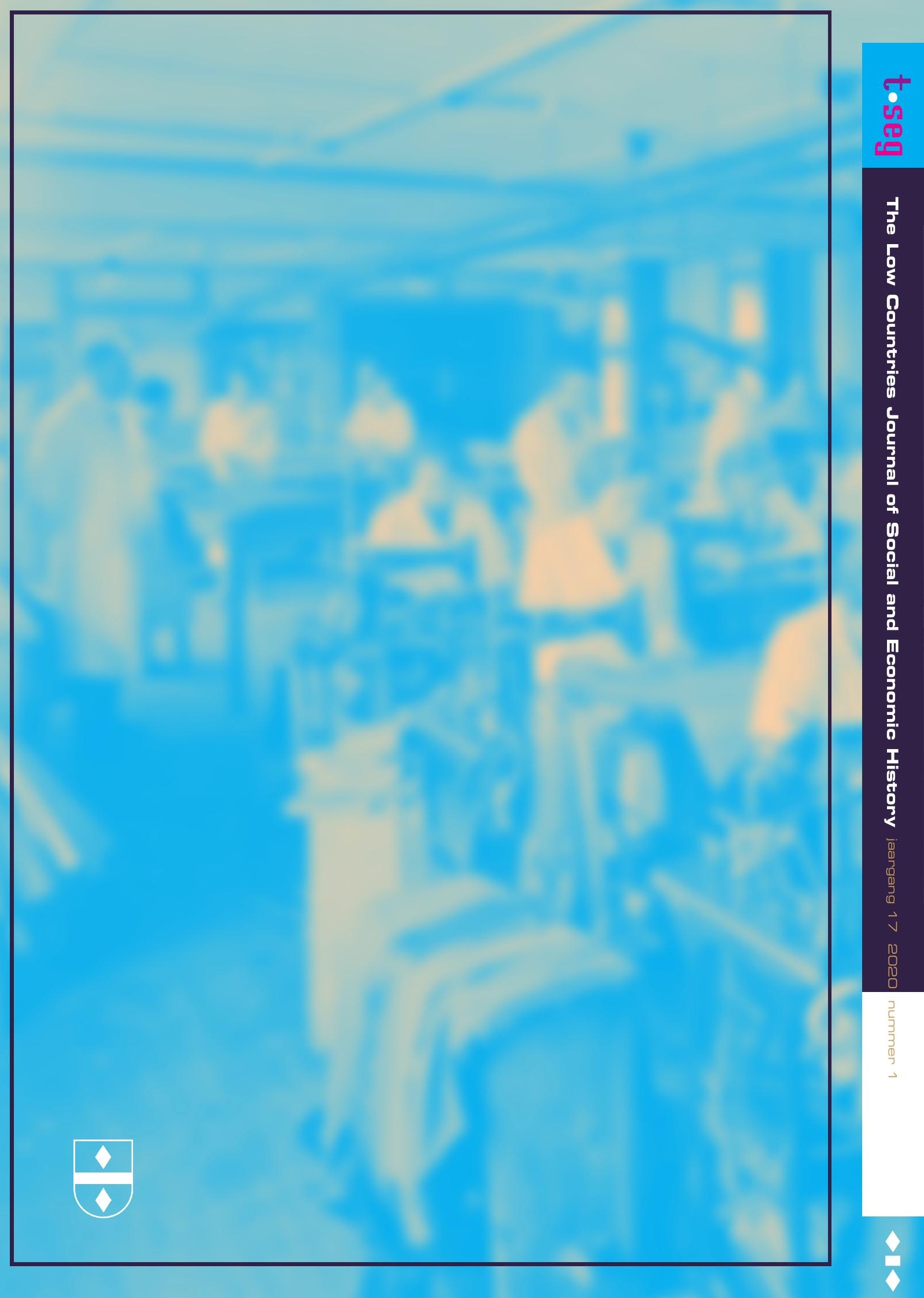

